\title{
Oceanographic and faunistic structures across an Angola Current intrusion into northern Namibian waters
}

\author{
H.-Ch. John ${ }^{\text {a,* }}$, V. Mohrholz ${ }^{\text {b }}$ J.R.E. Lutjeharms ${ }^{\mathrm{c}}$, S. Weeks ${ }^{\mathrm{d}}$, \\ R. Cloete $^{\mathrm{e}}$, A. Kreiner ${ }^{\mathrm{e}}$, D. da Silva Neto ${ }^{\mathrm{f}}$ \\ ${ }^{a}$ Deutsches Zentrum für Marine Biodiversität am Forschungsinstitut Senckenberg, c/o Zoologisches Institut und Museum, \\ Martin-Luther-King-Platz 3, Hamburg 20146, Germany \\ ${ }^{\mathrm{b}}$ Institut für Ostseeforschung, Seestraße 15, Warnemünde 18119, Germany \\ ${ }^{\mathrm{c}}$ Department of Oceanography, University of Cape Town, Rondebosch 7700, South Africa \\ ${ }^{\mathrm{d}}$ Ocean Space Remote Sensing, University of Cape Town, Rondebosch 7700, South Africa \\ ${ }^{\mathrm{e}}$ National Marine Information and Research Center, P.O. Box 912, Swakopmund, Namibia \\ ${ }^{\mathrm{f}}$ Departamento da Biologia Vegetal, University of Lisbon, Campo Grande, Ed. C2, Piso 4, Lisbon 1700, Portugal
}

Received 7 September 2001; accepted 20 November 2003

\begin{abstract}
It is thought that the penetration of Angolan waters through the Angola-Benguela Frontal Zone (ABFZ) into the much cooler Benguela regime may come about by a poleward slope undercurrent as well as by cross-frontal filaments. To test this hypothesis, two zonal transects off the northern Namibian coast were surveyed by CTD casts, current measurements and ichthyoplankton samples during April 1999. Simultaneous sea-surface temperature (SST), chlorophyll-a concentration, and wind data were obtained from satellite. The multidisciplinary results are described.

An intense intrusion of the Angola Current into northern Namibian waters occurred with distinct signals of high temperatures and salinities, low chlorophyll-a concentration, and Angolan fish larvae of both the neritic and oceanic communities. This intrusion was temporarily displaced offshore by strong southeasterly winds, which also caused coastal upwelling and enhanced productivity. The expected slope undercurrent was not found. The Benguela Upwelling Front coincided with a sharp boundary between equatorward flow inshore, and generally southward flow offshore, whilst the offshore component of the AngolaBenguela Frontal Zone was located much farther south than anticipated, and showed only weak temperature gradients.

Inshore of the Benguela Upwelling Front temperate Benguela fauna had characteristics of anomalously warm conditions. Tropical fish larvae offshore were clearly related to advection in Angola Current water, but not to recent spawning of their parents in it. Inconsistencies were observed in some cross slope boundaries between oceanic versus neritic fish larvae that can only partly be explained by Ekman drift of the surface layer, indicating that both the hydrographic and faunistic structures resulted from opposing meridional flows over time scales as different as 6 days to 4 weeks, intense mixing in the friction zone between them, and the westward displacement of a mesoscale gyre contributing its own anticyclonic flowfield. A conceptual transport model is presented.
\end{abstract}

(C) 2004 Elsevier B.V. All rights reserved.

Keywords: Northern Namibia; Angola Current Intrusion; Benguela Upwelling Front; Zonal transects; Hydrography; Fish larvae

* Corresponding author. Tel.: +49-40-428-385-642; fax +49-40-428-383-937.

E-mail address: HCJOHN@zoologie.uni-hamburg.de (H.-Ch. John). 


\section{Introduction}

The Angola-Benguela Frontal Zone (ABFZ; see, e.g., the review by Kostianoy and Lutjeharms, 1999) is the convergence zone between the Angola Current and the Benguela Current (Shannon, 1985), separating tropical Angolan waters from the cool Benguela upwelling regime. The ABFZ oscillates seasonally by some $3^{\circ}$ of latitude, is on average centered at about $16^{\circ} \mathrm{S}$, and is about $2^{\circ}$ of latitude wide nearshore, much broader offshore (Meeuwis and Lutjeharms, 1990). This frontal zone is not impermeable, but is occasionally breached by warm, Angolan water from the north. This can take the form of small intrusions (e.g., Mohrholz et al., in press) or major events (Shannon et al., 1986). The latter, called Benguela Niños, have recently been shown to be the result of changes in wind stress patterns in the equatorial Atlantic Ocean (Florenchie et al., 2003).

Biological cross frontal surveys have been undertaken for the first time only recently. The ABFZ proved to be a zoogeographical boundary for mesopelagic fish species (John et al., 2001), and should generally limit the distribution of tropical species towards the south, and that of cold water forms towards the north (as anticipated by Longhurst, 1962). Fish larval abundances in shelf and slope waters have to date been found to be highest north

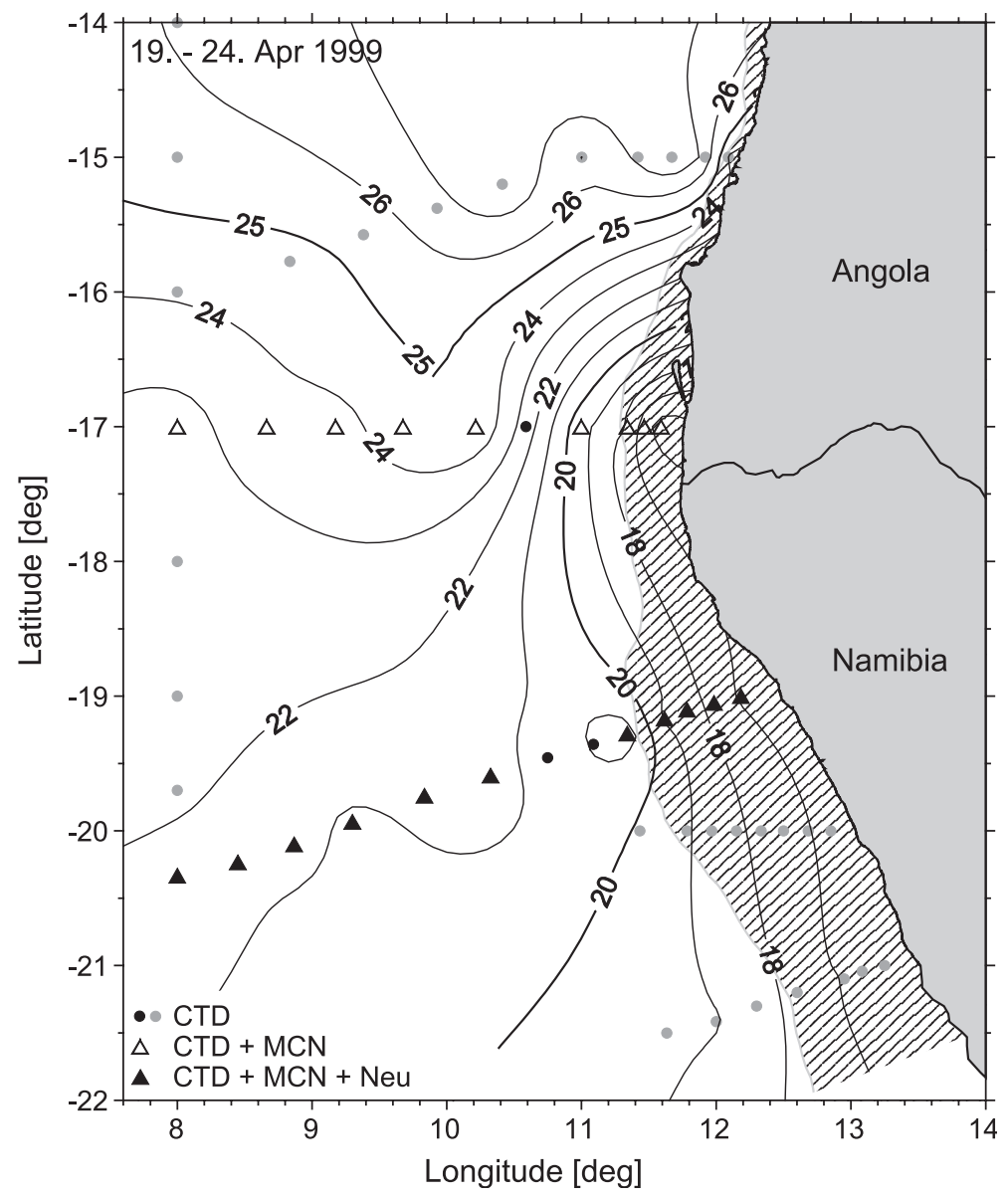

Fig. 1. The stations investigated and temperatures at $20 \mathrm{~m}$ depth (from John et al., 2001, modified). All stations include CTD casts (dots to triangles). Triangles represent the two cross-coast surveys described here in detail. Open triangles depict additional multinet sampling, solid triangles where besides CTD casts and multinet hauls the neuston net was deployed. The area with water depths less than $500 \mathrm{~m}$ is shaded. 
of the ABFZ, and lowest south of it (Ekau et al., 2001; Mayfield et al., 2001).

Olivar and Fortuño (1991) related the inconsistent occurrence of tropical Vinciguerria nimbaria larvae, plus some other warm water species, to the seasonal intrusion of warm Angolan waters into the northern Benguela regime. During such an intrusion fish larval diversity had increased (Olivar, 1990). Olivar and Shelton (1993) have listed several tropical species as latitudinally restricted there. The respective catch localities in slope waters were documented by Olivar and Fortuño (op. cit.) and used by John et al. (2000) to hypothesize that there exists a similarity here with transport processes for the same species across the Cape Verde Frontal Zone. This cross-front transport was believed to occur by a submergence of the Angola Current at the front, continuing as a poleward slope undercurrent southwards to perhaps $33^{\circ} \mathrm{S}$. John et al. (2000) have assumed that cross-frontal transport might also occur by filaments in the open ocean. In a recent cross-front survey in the open ocean $V$. nimbaria (first ranking species in the Angolan open ocean) indeed occurred beyond the ABFZ in smaller numbers as far south as $20^{\circ} \mathrm{S}$ (John et al., 2001). However, it remains uncertain whether this situation is indicative for cross-frontal dispersal, or a mere rudiment of the hydrographical situation a few days previously when the ABFZ had a more southern position (Mohrholz et al., in press).

The survey described here was originally designed to investigate the question whether, where and how poleward fish larval transport across the ABFZ occurs. The biological survey comprised two crossshore transects from $8^{\circ} \mathrm{E}$ to the coast (Fig. 1). The northern transect was located at $17^{\circ} \mathrm{S}$ with the intention to sample the southern part of the ABFZ as being representative of the potential source region, and the second transect near $20^{\circ} \mathrm{S}$ was expected to cross the expected poleward pathways some $2-3^{\circ}$ farther south. The results described below, however, were strongly influenced by a long-term, intense intrusion of Angola Current waters into Namibian waters, and its offshore displacement by an upwelling event. Consequently, the biological and hydrographical patterns observed are representative for very different time scales in the biological, compared to the hydrographical parameters than was originally expected. Nonetheless, it allows for the first description of the hydrographic and faunistic structures across an Angola Current Intrusion (ACI).

\section{Material and methods}

In April 1999, the German RV "Poseidon" surveyed a multidisciplinary station grid from northern Angola to northern Namibia, and from $8^{\circ} \mathrm{E}$ to nearshore waters, which covered the eastern part of the Angolan Gyre, the ABFZ and the northern Benguela upwelling regime as well. A detailed description of the purpose of the survey, stations covered, methods, calibration, and basic results has been published in a data report (Schmidt et al., 2000). This paper focuses on the results of two transects at the ABFZ. The northern transect along $17^{\circ} \mathrm{S}$ was conducted from the afternoon of 19 April (nearshore, station 216) to the early morning of 21 April at $8^{\circ} \mathrm{E}$ (station 225). The southern transect started offshore on 22 April in the afternoon and ended nearshore on 24 April in the evening (stations 229-241). The temperature distribution at $20 \mathrm{~m}$ depth (Fig. 1) was based on additional CTD casts beyond the two transects described here (see John et al., 2001).

CTD stations were carried out using a Seabird $911+$ CTD, that was additionally equipped with a two-channel fluorometer (chlorophyll-a fluorescence at $683 \mathrm{~nm}$ and backscattering at $520 \mathrm{~nm}$ ). After postprocessing the accuracy of temperature and salinity amounts to $0.006 \mathrm{~K}$ and 0.003 , respectively. During the entire cruise a vessel-mounted Acoustic Doppler Current Profiler (VADCP) was used to obtain the current field from the near surface down to $400 \mathrm{~m}$ depth. The current data were processed with the CODAS software package (Firing et al., 1995). The residual error of the current data was estimated as 3-4 $\mathrm{cm} \mathrm{s}^{-1}$. Underway measurements of surface temperature, surface salinity and meteorological data completed the hydrographic data set. The weekly mean wind fields for the area of the ABFZ were derived from the ERS2 wind data set (www.ifremer.fr). Intermittent, high resolution $(1 \mathrm{~km})$, surface distributions of chlorophyll-a were compiled from SeaWiFS satellite data. This data provided information about mesoscale structures in the upper layer during the life span of the fish larvae caught, which could not be obtained from the station grid. 
The analysis of fish larvae abundance, community structure and cross-coast zonation was based on oblique quantitative plankton tows by a Bé-multipleopening-closing net of $0.25 \mathrm{~m}^{2}$ mouth area (MCN), carried out closely to each CTD station. The MCN hauls yielded five depth strata $(0-25,25-50,50-100$, $100-150$ and $150-200 \mathrm{~m}$ ) from the surface down to $200 \mathrm{~m}$ depth. The nets of $300-\mu \mathrm{m}$ mesh size each were equipped with calibrated flow-meters (Hydro-Bios) and towed at ship speeds of $1.3-1.5 \mathrm{~m} \mathrm{~s}^{-1}$ (for details, see John et al., 2001). Strong winds prevented one station at $17^{\circ} \mathrm{S}$ and three central stations along $20^{\circ} \mathrm{S}$ being sampled, thus reducing the intended number of stations to 9 at $17^{\circ} \mathrm{S}, 10$ at $20^{\circ} \mathrm{S}$. Along the southern transect, a neuston net (NEU) was also deployed, as done previously for the survey across the ABFZ (John et al., 2001). The gap in the distribution of these data is smaller, but at station 239 the upper neuston net broke due to large amounts of plankton, and instead the slightly deeper reference NEU sample (undersampling neustonic species) was used to check the occurrence and lengths of neritic fish larvae. Abundance values are expressed below by unit areas of $1000 \mathrm{~m}^{2}$ for NEU and $1 \mathrm{~m}^{2}$ for MCN, closest to the actual effort used and as recommended as standard unit by Ahlstrom (1973). The NEU sampled on average $904.7 \mathrm{~m}^{2}\left( \pm 660.2 \mathrm{~m}^{2}\right.$; $N=11)$ and all MCN strata on average $3.8 \mathrm{~m}^{2}( \pm 1.18$ $\left.\mathrm{m}^{2} ; N=88\right)$. Since opening-closing depths of the $\mathrm{MCN}$ were monitored in real time, catch per volume data (concentrations) could be correctly converted to abundance values per step, or integrated to a layer comprising 0-200 m (Ahlstrom, 1973). Mean vertical distributions were calculated from abundances per step as mean-weighted depth $\mathrm{MWD}=\Sigma\left(n_{i} d_{i}\right) N_{i}^{-1}$, with $n_{i}$ being the abundance in stratum $i, d_{i}$ the mean depth of stratum $i$, and $N_{i}=\sum n_{i}$. Parameters describing commu- nity structures were calculated after Whittaker (1975). Whittaker's "Percentage Similarity Index" compares the relative abundances of any species, contrary to indices based on presence/absence of a species.

The plankton was originally preserved and stored in a buffered $4 \%$ formaldehyde/seawater solution. Extracted larvae were preserved in a 2\% Steedman/ formaldehyde solution (Steedman, 1976). Material from $17^{\circ} \mathrm{S}$ has been deposited at the National Marine Information and Research Centre at Swakopmund, that from $20^{\circ} \mathrm{S}$ at the Zoologisches Museum, Hamburg. Lengths, as an indicator of (at least relative) age, were measured to the lower $0.1 \mathrm{~mm}$ in sizes smaller than $10.0 \mathrm{~mm}$, and in $1 \mathrm{~mm}$ size classes above. Age estimates for pilchard (the traditional name pilchard is becoming replaced by sardine) and anchovy were possible by keys on live lengths (Table 1), and lengths measured from preserved larvae of these two species were corrected for shrinkage by adding $10 \%$ to the notochord or standard length (NL or SL, respectively). The growth values listed for pilchard were taken from King (1977) and Thomas (1986). The values for anchovy were taken from Brownell (1983), King et al. (1978) and (partly) Thomas (1986). However, in light of the small hatching length of anchovy, we assume lower growth rates for the days of first feeding than the constant increment of $0.5 \mathrm{~mm} /$ day stated by Thomas (1986). Minimum as well as modal lengths of Cape horse mackerel (Trachurus trachurus) were distinctly smaller than the material on which King et al. (1977) had based their growth data, even after tentative correction for shrinkage. In contrast, our material conformed better with an earlier age/length key from other, mostly North Atlantic, preserved larvae (John et al., 1991, Table 4). Length data for horse mackerel, and those other species for which no

Table 1

Growth data for the back-calculation of pilchard and anchovy birthdays (for details and references, see text)

\begin{tabular}{lllll}
\hline & \multicolumn{1}{c}{ Pilchard=Sardine Sardinops ocellatus } & \multicolumn{1}{c}{ Anchovy Engraulis capensis } \\
\hline Temperature & $17{ }^{\circ} \mathrm{C}$ & $20{ }^{\circ} \mathrm{C}$ & $17{ }^{\circ} \mathrm{C}$ & $20{ }^{\circ} \mathrm{C}$ \\
Spawning to hatch & 2 days & 1.5 days & 2 days & 1.5 days \\
Hatch to first feeding & 3 days & 2.5 days & 3 days & 2 days \\
Length at first feeding & $5.75 \mathrm{~mm}$ & $5.75 \mathrm{~mm}$ & $3.70 \mathrm{~mm}$ & $3.8 \mathrm{~mm}$ \\
Daily growth at first feeding & constant; & constant; & increasing; $0.2,0.3$, & increasing; $0.2,0.3$, \\
& $0.6 \mathrm{~mm} /$ day & $0.8 \mathrm{~mm} /$ day & $0.4 \mathrm{~mm} /$ day & $0.4 \mathrm{~mm} /$ day \\
Daily growth after first feeding & constant; & constant; & constant; & constant; \\
& $0.6 \mathrm{~mm} /$ day & $0.8 \mathrm{~mm} /$ day & $0.5 \mathrm{~mm} /$ day & $0.6 \mathrm{~mm} /$ day \\
\hline
\end{tabular}


age/length information is available, have therefore not been corrected for shrinkage.

Classification of fish larvae into communities such as Tropical Neritic (TN), Tropical Oceanic (TO), Central Water (CW), Southern Neritic (SN) and Southern Oceanic (SO) are here understood as adult habitat relative to the survey area. Thus, for example, species with a boundary at or slightly north of $17^{\circ} \mathrm{S}$ are distinguished as tropical versus southern; whilst warm water species like, e.g., Parablennius pilicornis, occurring as far south as Möwe Point $\left(19^{\circ} \mathrm{S}\right)$ were grouped together with the widely spread neritic species T. trachurus into the Neritic Ubiquitous/Uncertain group NU. In the same way oceanic taxa occurring across $17^{\circ} \mathrm{S}$, or not identifiable as discretely distributed species, were grouped as Oceanic Ubiquitous/Uncertain (OU). The faunistic allocations of taxa of any abundance will be listed further below. No
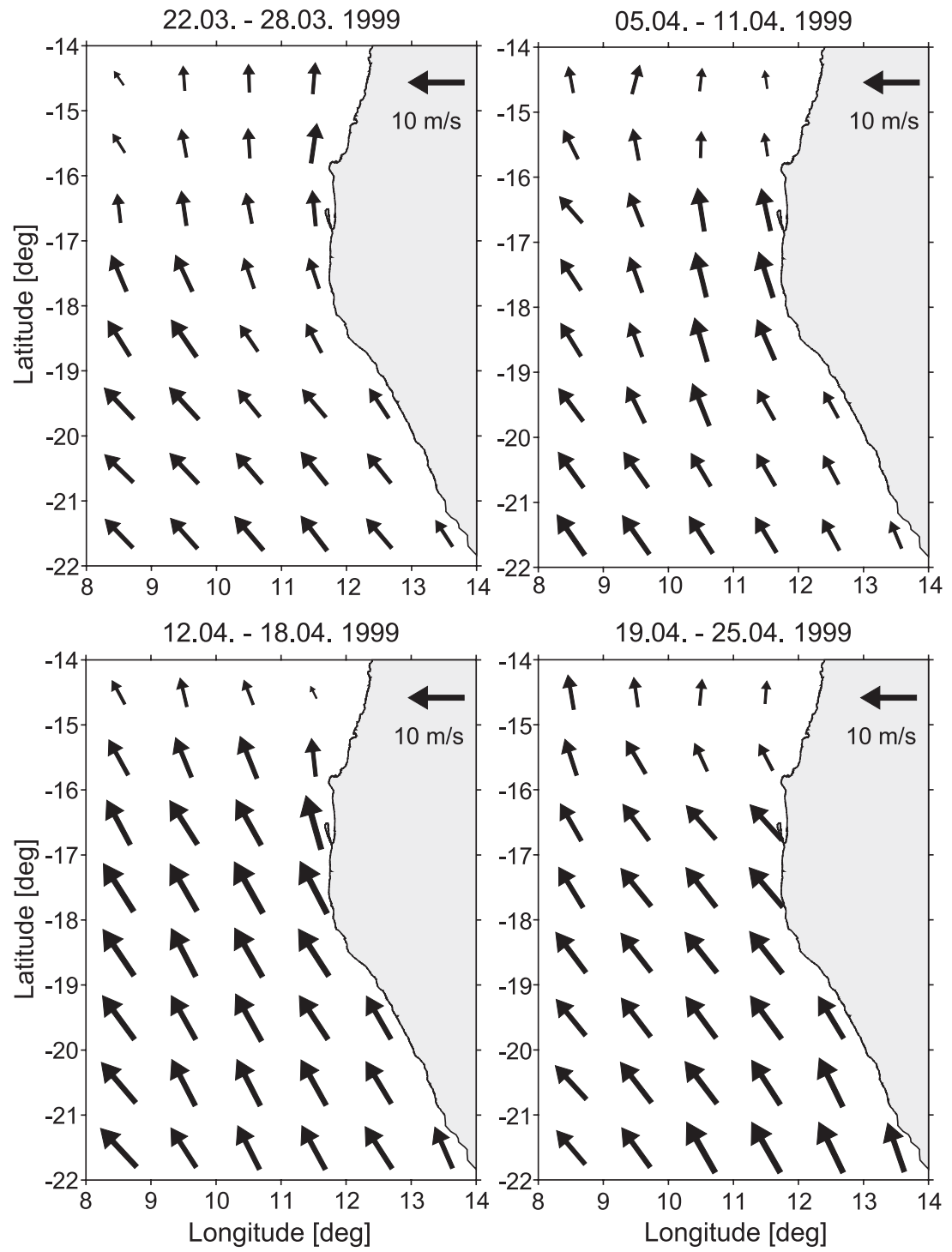

Fig. 2. Weekly mean winds in the survey area for the likely spawning and drift period of fish larvae. Winds in the period 29 March -4 April were similar as shown for 22-28 March. Data were derived from ERS2 (www.ifremer.fr). 
typical members of the slope community were encountered; the allocation of respective questionable specimens will be mentioned in detail. Distributional information on adults of the species in question was extracted for mesopelagic species from Bekker (1983), Hulley (1981), Nafpaktitis et al. (1977), Johnson (1986) and John et al. (2000). The smallscale zoogeography of coastal species was investigated by Penrith (1978). More general sources for the above, and particularly the remaining taxa, were taken from the compilations in Smith and Heemstra (1986), Olivar and Fortuño (1991) and CLOFETA (1990). Some taxonomically questionable species names are indicated by question marks. These identifications generally follow Olivar and Fortuño (1991). Bathylagus tenuis? is identified from Olivar et al. (1993), and Diaphus taaningi? is a tentative identification by ourselves.

\section{Results}

\subsection{Hydrography}

In order to understand the distribution of fish larvae at their time of catch, the development of the hydrographic situation has to be considered over their entire preceding life span. Both the data gathered on board, as well as satellite data on surface temperature and wind stress, show that important changes occurred in meteorological and hydrographical conditions during the survey, most noticeably by the
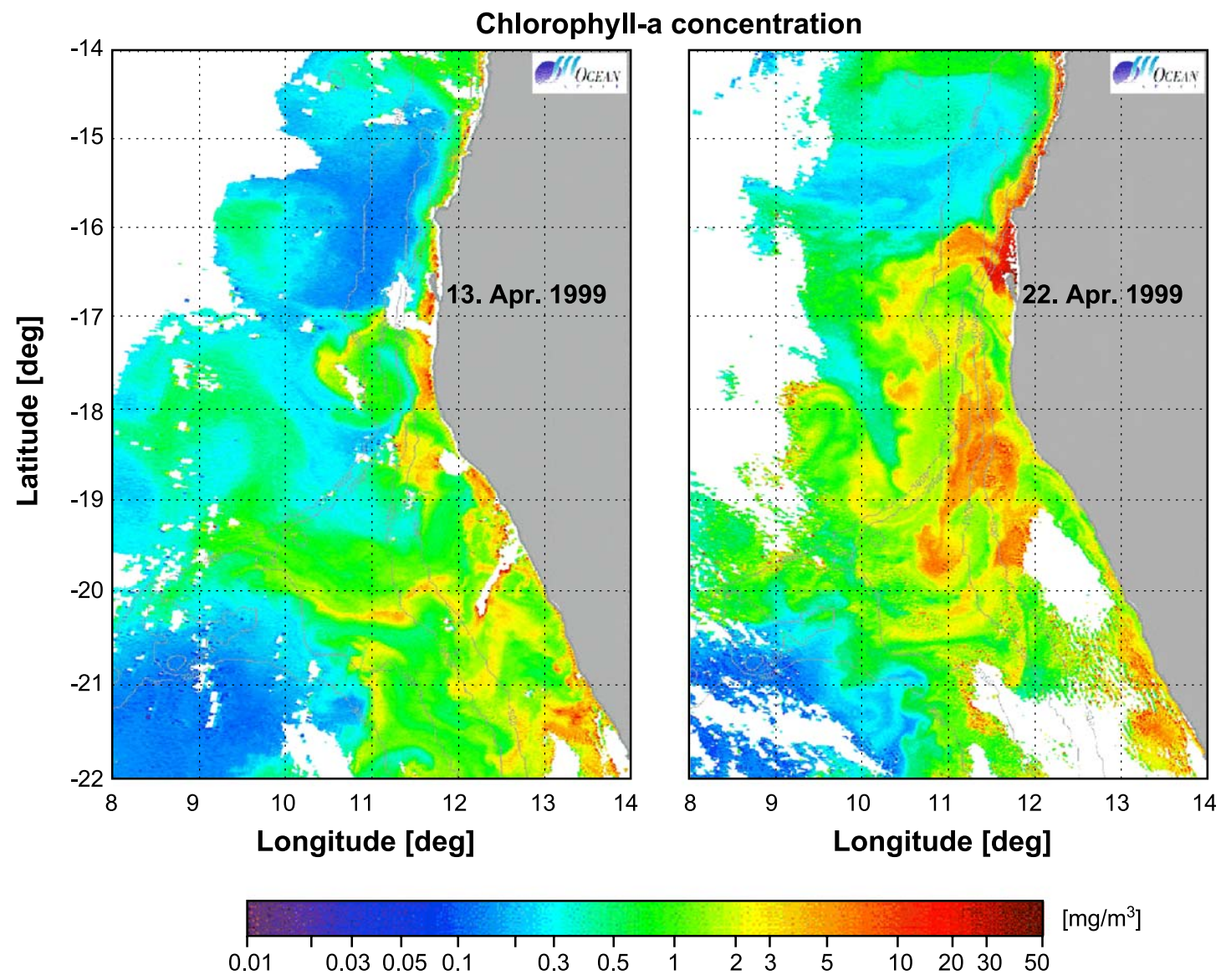

Fig. 3. Surface chlorophyll-a concentrations at the end of the quiescent situation (left panel), and at the time the biological samples were taken (right panel) 1 week after the onset of strong winds and upwelling. 

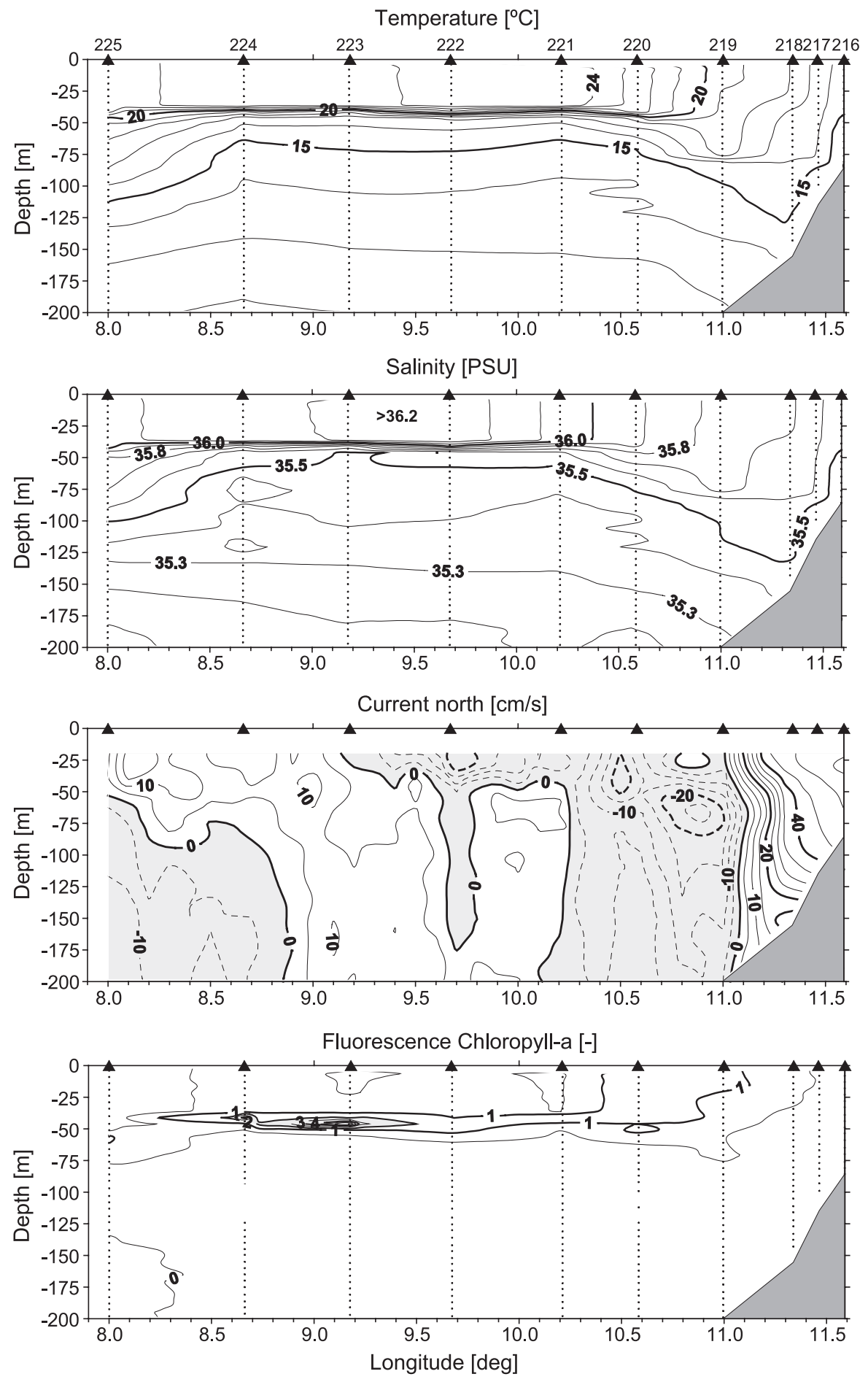

Fig. 4. The zonal environmental structure along $17^{\circ} \mathrm{S}$. Upper panel: temperature. Second panel: salinity. Third panel: current vector north from $\mathrm{ADCP}$ data (white $=$ equatorward, shaded = southward). Bottom: relative chlorophyll concentration as expressed by fluorescence (arbitrary units). 

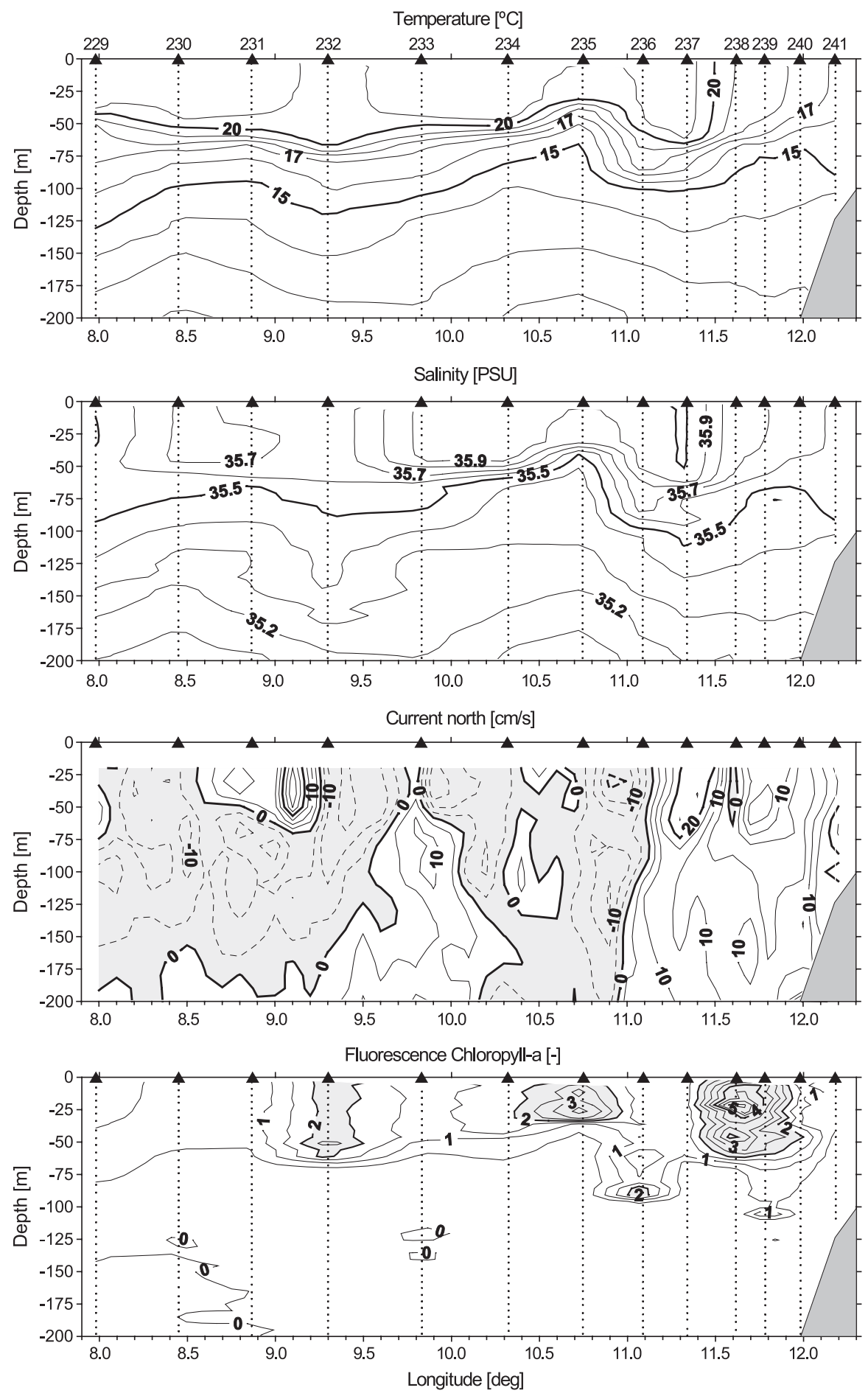

Fig. 5. The zonal environmental structure along $20^{\circ} \mathrm{S}$. Same as in Fig. 4. 
enforcement and equatorward displacement of the ABFZ shortly before running the two biological transects. Except for the interpretation of SeaWiFS images, the following summary combines the descriptions by John et al. (2001, displacement of the ABFZ and nonsynoptic subsurface temperatures), Mohrholz et al. (2001, for the horizontal and vertical structures of water masses and currents), and Mohrholz et al. (in press) with emphasis on meteorology and time scales. The three above cited papers interpreted the hydrographical situation as a Benguela Niño, temporarily influenced in Namibian nearshore waters by an upwelling event.

At the end of March the ABFZ was found at $19^{\circ} \mathrm{S}$, an unusual southern position. An intense intrusion of the Angola Current transported warm saline water along the slope southwards. Due to weak winds (see Fig. 2), coastal upwelling was interrupted. Water temperatures off northern Namibia exceeded $20{ }^{\circ} \mathrm{C}$ near-shore and $23{ }^{\circ} \mathrm{C}$ offshore. The ACI proper had low chlorophyll-a concentrations $<0.5 \mathrm{mg} / \mathrm{m}^{3}$, but the ABFZ showed concentrations $>3.0 \mathrm{mg} / \mathrm{m}^{3}$ from the coast to $9.7^{\circ} \mathrm{E}$. Until 13 April, the chlorophyll-a concentration decreased to a narrow coastal band, some few filaments south of $17^{\circ} \mathrm{S}$, and a narrow frontal band at the ACI's southern tip at $20^{\circ}$ (Fig. 3, left panel). The onset of the Southeast Trade wind in the second half of April reinforced the coastal upwelling south of $16^{\circ} \mathrm{S}$. This resulted in the development of a coastal belt of cold upwelled water, a westward displacement of the ACI due to the Ekman offshore transport, and elevated chlorophyll-a concentrations of 3.0 to $>10.0 \mathrm{mg} / \mathrm{m}^{3}$, from the coast to $10^{\circ} \mathrm{E}$ and between latitudes $16^{\circ}$ and $20^{\circ} \mathrm{S}$ (Fig. 3).

The distributions of hydrographic parameters at both transects display similar general features. As expressed by the horizontal temperature distribution (Fig. 1), both transects crossed the nearshore upwelling front almost perpendicularly at a distance of 60 nautical miles off the coast, but slanted across the offshore extent of the ABFZ, which showed weaker temperature gradients (Fig. 1). The Benguela upwelling regime with a northward current determined the circulation at the shelf, whereas the southward intrusion of the tropical Angola Current waters dominated the offshore conditions, particularly in the north. The core of the Angola Current intrusion is depicted in Fig. 4 by temperatures $>21^{\circ} \mathrm{C}$ and salinities $>35.9$, whilst Benguela surface waters normally have surface salinities < 35.5 (Shannon et al., 1987).

The nearshore slopes of the isotherms at $17^{\circ} \mathrm{S}$, and somewhat less at the southern transect, might be interpreted as indicative of a poleward undercurrent, but this is contradicted by both the in-situ ADCP data as well as the absence of any signal for elevated salinity, not even at larger depths. Indications for an undercurrent were, however, found off southern Angola a few days earlier (Schmidt et al., 2000).

By contrast, the southern transect crossed several eddy-like structures embedded in the main circulation (Fig. 3, right panel; Fig. 5), but the station grid was too coarse (apart from lacking three-dimensionality) for a reasonable resolution of these mesoscale features. The vertical gradients between the ACI and the underlying thermocline water were much weaker than at the northern transect and the surface mixed layer increased from $40 \mathrm{~m}$ at $17^{\circ} \mathrm{S}$ to $60 \mathrm{~m}$ at $20^{\circ} \mathrm{S}$. This suggests enhanced mixing by mesoscale eddies.

\subsection{Gross community structure parameters}

Along $17^{\circ} \mathrm{S}$ fish larvae showed low gross abundance (Table 2). Relative abundance maxima occurred offshore and near the coast (Fig. 6), with minimum values in the core of the Angola Current intrusion (compare Fig. 4). The highest abundance values did not coincide with maxima of chlorophyll, but to some degree with vertical expansions of the pycnocline both nearshore, and offshore (not shown, but expressed by temperature and salinity in Fig. 4).

Taxa richness and diversity were high offshore, but much lower in the Angola Current. Richness and

Table 2

Gross community structure parameters from north of the ABFZ (data from John et al., 2001), and the two transects surveyed here

\begin{tabular}{|c|c|c|c|}
\hline Transect & 14 and $15^{\circ} \mathrm{S}$ & $17^{\circ} \mathrm{S}$ & $20^{\circ} \mathrm{S}$ \\
\hline$N$ hauls (MCN only) & 2 & 9 & 10 \\
\hline$N$ specimens & 835 & 189 & 749 \\
\hline$N$ identified & 828 & 164 & 671 \\
\hline$N$ taxa & 31 & 41 & 43 \\
\hline Mean $N / 1 \mathrm{~m}^{2} \pm$ S.D. & 128.6 & $5.9 \pm 5.5$ & $24.4 \pm 18.6$ \\
\hline Median $N / 1 \mathrm{~m}^{2}$ & & 3.8 & 22.1 \\
\hline Mean depth MWD [m] & 40.3 & 38.3 & 32.6 \\
\hline Diversity, $H^{\prime}$ & 1.75 & 3.21 & 2.51 \\
\hline Evenness, $J^{\prime}$ & 0.51 & 0.87 & 0.67 \\
\hline Similarity PSI & 0.33 & 0.28 & \\
\hline
\end{tabular}




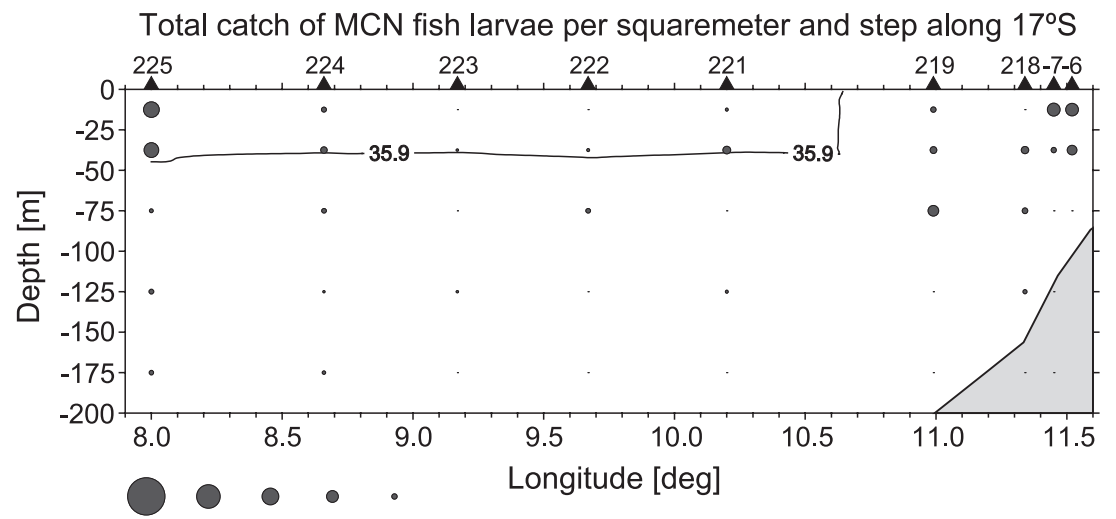

$\begin{array}{llllll}50 & 20 & 10 & 5 & 1 & {\left[\mathrm{n} / \mathrm{m}^{2}\right]}\end{array}$
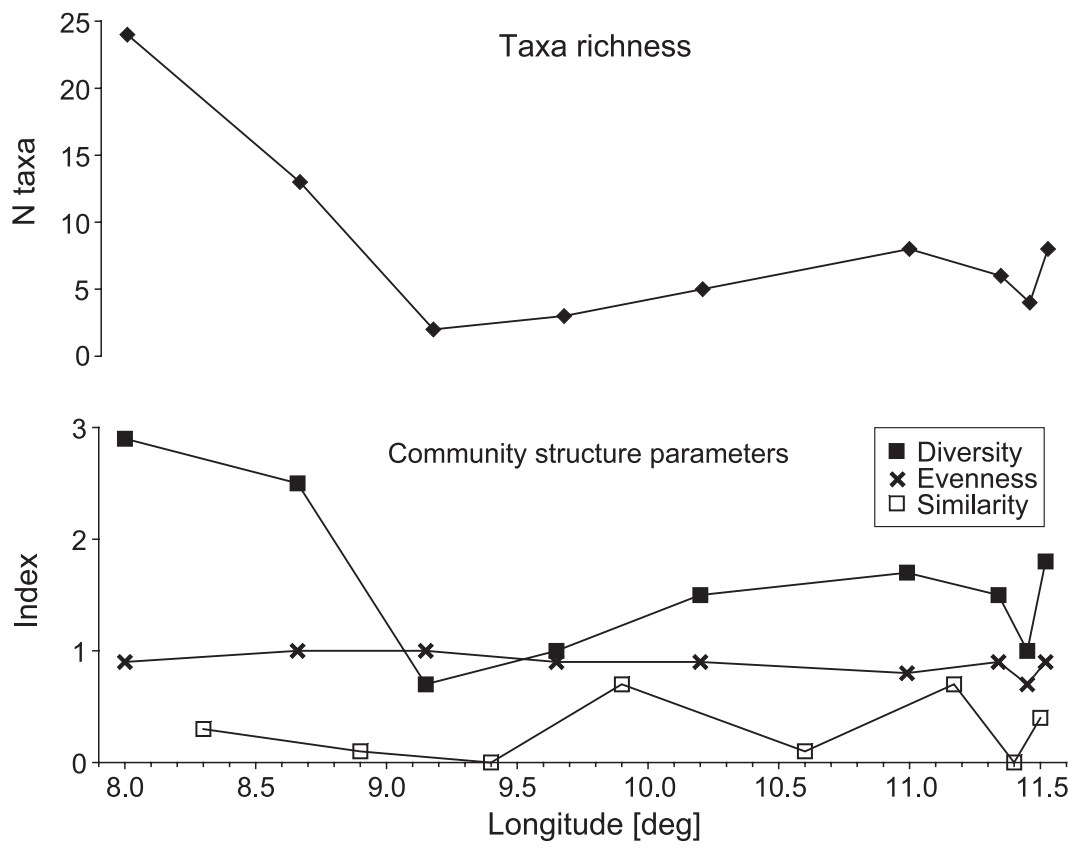

Fig. 6. The zonal fish larval community structure along $17^{\circ} \mathrm{S}$. Upper panel: gross abundance per square meter and step. The core of the ACI is depicted by $S=35.9$. Middle panel: taxa richness per station. Lower panel: indices per station of diversity and evenness, and similarity (decimal fractions, weighted by relative abundance of any taxon) between neighbouring stations.

diversity increased slowly towards the coastal jet (characterised by lower surface temperatures, an uplift of isopleths in the vertical sections, and equatorward flow in the ADCP data nearshore). There were no truly dominating species, but a higher number of rare taxa amounting to $27 \%$ of the total (Tables 2 and 3), and the similarity between adjacent stations was generally low. The high gross index of diversity and evenness, and the low similarities between both transects and stations are a consequence of a highly diverse but little abundant tropical fauna in the north. In the gross comparison (Table 2), the Angolan open ocean data do not include coastal stations, which explains the lower number of taxa and deeper vertical distribution. However, for all other parameters bias is small since only three neritic taxa contributed noticeable numbers to the gross data from $17^{\circ} \mathrm{S}$. 
The southern transect yielded on average catches four times higher than the one to the north, albeit much lower than in the Angolan Gyre (John et al., 2001). The partly incomplete data again show some decrease of abundance, taxa richness, and similarity in the core of the Angola Current (Fig. 7), which was much narrower than in the north. The fish larval maximum nearshore coincided with the distinct gyral structure there, whilst the offshore chlorophyll-a maximum could not be traced in the fish larval distribution and was a small-scale feature only evi- dent in the synoptic SeaWiFS image (Fig. 3). Regrettably the central stations showing the third gyre above an uplift of the pycnocline could not be sampled for zooplankton, which caused or enhanced some inconsistencies in the collected data. This uplift coincided also with a spot of lower $\left(20^{\circ} \mathrm{C}\right)$ surface temperatures in a synoptic SST satellite image (Fig. 15 , used as background for the transport model at the end of this paper). The overall number of species was similar to that at the northern transect, nevertheless gross diversity decreased and the similarity
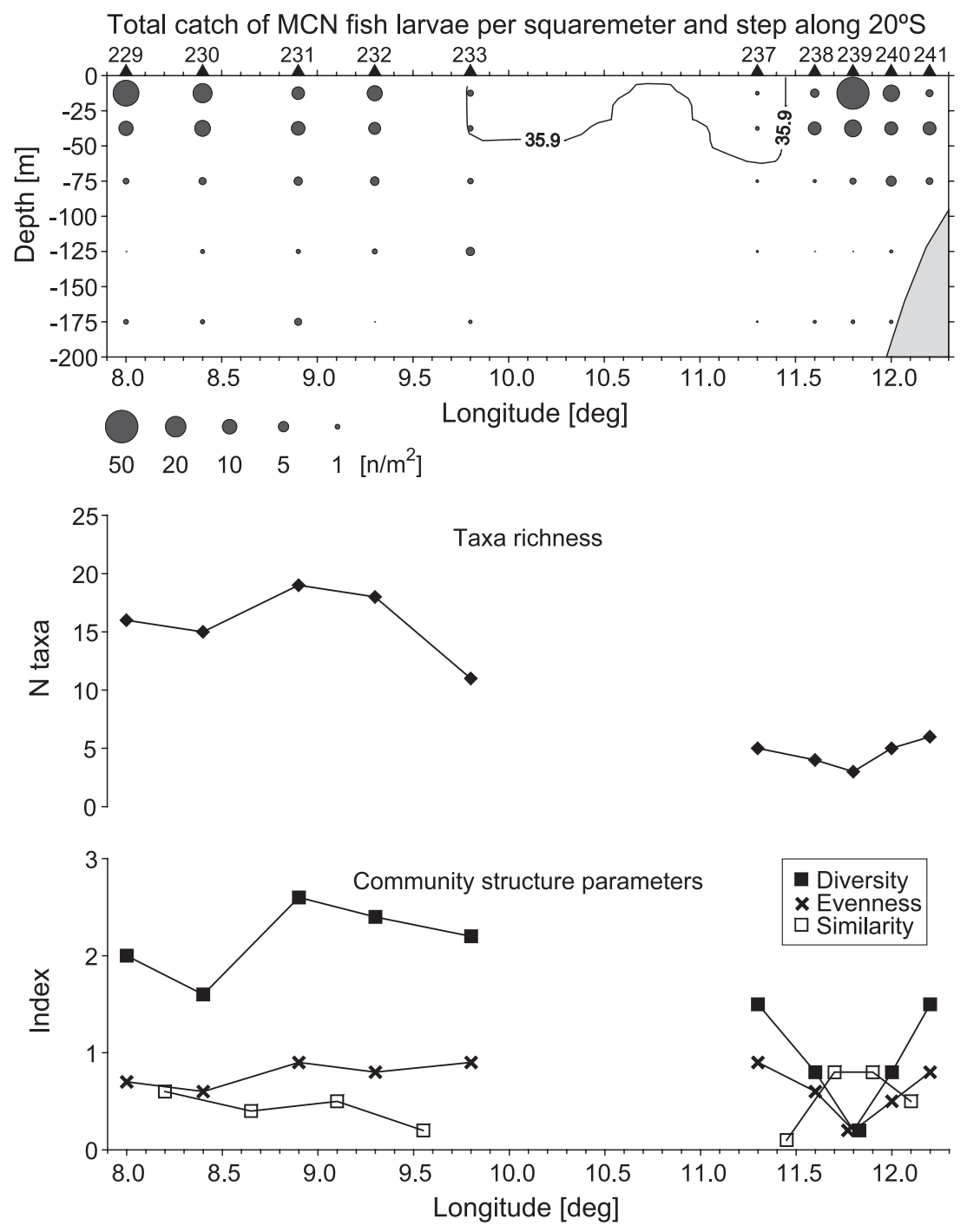

Fig. 7. The zonal fish larval community structure along broadly $20^{\circ} \mathrm{S}$. Same as in Fig. 6 . 
with the northern transect was low (Table 2). This is largely caused by the change in species composition evident in Table 3.

Diversity values remained high all along the oceanic part of the transect and probably across most of the gap in the sampling as well. Diversity values dropped and similarity increased in the Benguela regime east of $11.5^{\circ} \mathrm{E}$, again showing upwelling structures as at $17^{\circ} \mathrm{S}$. Low values for evenness, and rank order data show that dominating species were found, but apparently differed offshore and nearshore. Species of the central South Atlantic and the southern open ocean occurred, and the overall character was less tropical.

\subsection{Tropical species}

Along $17^{\circ} \mathrm{S}$, the distribution of larvae of tropical species revealed good conformity with the water mass and current structure (Fig. 8). Tropical neritic elements at $17^{\circ} \mathrm{S}$ were 1 Acanthurus monroviae, 4 Bothus podas and 1 Microdesmus longipinnis. They must have originated from shallow Angolan shelf waters, where the Angola Current lies adjacent to the coast. However, along this transect they generally were confined to the offshore area that had temperatures $>19^{\circ} \mathrm{C}$, salinity $>36.0$, and southward flow. This conformed to the offshore displacement of the Angola Current within

Table 3

The first ranking taxa and their allocation to faunistic communities

\begin{tabular}{|c|c|c|c|c|c|}
\hline Transect & & $\mathrm{MCN} 17^{\circ} \mathrm{S}$ & $\mathrm{MCN} 20^{\circ} \mathrm{S}$ & NEU $20^{\circ} \mathrm{S}$ & \\
\hline Area sampled, total $\left[\mathrm{m}^{2}\right]$ & & 34.4 & 39.5 & 9772.2 & \\
\hline Fish total $[\mathrm{N}]$ & 1686 & 189 & 749 & 748 & \\
\hline Taxon & & & & & Community type \\
\hline Scomberesox saurus & 550 & 0 & 0 & 550 & SO \\
\hline Trachurus trachurus & 266 & 4 & 242 & 20 & NU \\
\hline Ceratoscopelus warmingi & 141 & 8 & 131 & 2 & $\mathrm{OU}$ \\
\hline Parablennius pilicornis & 123 & 6 & 12 & 105 & NU \\
\hline Lepidophanes guentheri & 77 & 6 & 71 & 0 & OU \\
\hline Hygophum macrochir & 42 & 23 & 12 & 7 & TO \\
\hline Notoscopelus resplendens & 41 & 9 & 32 & 0 & $\mathrm{OU}$ \\
\hline Engraulis capensis & 28 & 0 & 27 & 1 & SN \\
\hline Stomiatoidei & 26 & 5 & 21 & 0 & OU \\
\hline Symbolophorus kreffti & 24 & 2 & 9 & 13 & TO \\
\hline Nanichthys simulans & 20 & 0 & 0 & 20 & $\mathrm{CW}$ \\
\hline Melamphaeidae & 18 & 2 & 16 & 0 & $\mathrm{OU}$ \\
\hline Sardinops ocellatus & 18 & 18 & 0 & 0 & SN \\
\hline Diaphus sp. & 15 & 11 & 4 & 0 & OU \\
\hline Exocoetus spp. & 14 & 0 & 0 & 14 & TO \\
\hline Lampridiformes & 13 & 3 & 10 & 0 & OU \\
\hline Vinciguerria nimbaria & 13 & 13 & 0 & 0 & TO \\
\hline TN complex (7 spp.) & 12 & 6 & 4 & 2 & $\mathrm{TN}$ \\
\hline Diogenichthys atlanticus & 11 & 1 & 10 & 0 & $\mathrm{OU}$ \\
\hline Paralepididae & 11 & 3 & 8 & 0 & OU \\
\hline Lobianchia dofleini & 10 & 0 & 10 & 0 & $\mathrm{OU}$ \\
\hline Cyclothone sp. & 10 & 6 & 4 & 0 & OU \\
\hline Hygophum bruuni? & 10 & 0 & 9 & 1 & SO \\
\hline Gobiidae & 8 & 6 & 2 & 0 & NU \\
\hline Bathylagus greyae & 8 & 0 & 8 & 0 & $\mathrm{OU}$ \\
\hline Bathylagus tenuis? & 6 & 0 & 6 & 0 & SO \\
\hline Diaphus taaningi? & 6 & 6 & 0 & 0 & $\mathrm{OU}$ \\
\hline Percent of above in total & 90.2 & 66.7 & 36.7 & 98.3 & \\
\hline
\end{tabular}

$\mathrm{N}=$ neritic, $\mathrm{O}=$ oceanic, $\mathrm{S}=$ southern, $\mathrm{T}=$ tropical, $\mathrm{CW}=$ Central Water and $\mathrm{U}=$ ubiquitous, or uncertain.

Numbers represent the actual catch. 


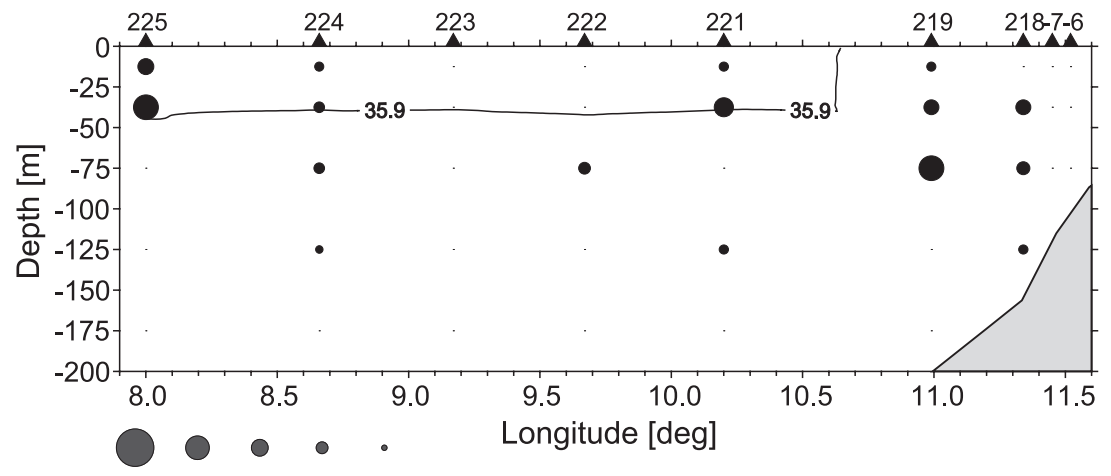

$\begin{array}{lllll}5.0 & 2.0 & 1.0 & 0.5 & 0.1\end{array}\left[\mathrm{n} / \mathrm{m}^{2}\right]$

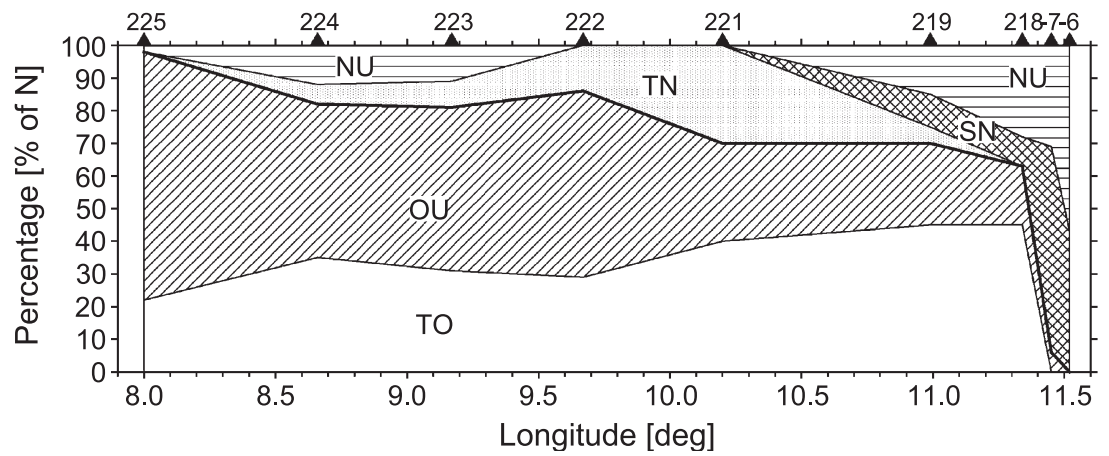

Fig. 8. The zonal and vertical abundance of fish larvae of tropical origin (upper panel, the core of the ACI is depicted by $S=35.9$ ), and the relative faunistic composition (lower panel) along $17^{\circ} \mathrm{S} . \mathrm{N}=$ neritic, $\mathrm{O}=$ oceanic, $\mathrm{T}=$ tropical, $\mathrm{S}=$ southern, $\mathrm{U}=$ ubiquitous or uncertain. For the respective species, see Table 3. Since at station 223, only 2 larvae had been caught, percentage values for this station are an average from stations $222-224$.

the ABFZ as a consequence of recent coastal upwelling and increased Ekman transport. The distribution of tropical oceanic species there (see Table 3, furthermore a single specimen each of Bathylagus argyrogaster, Bregmaceros sp. and Lampanyctus photonotus was found) showed a similar maximum of relative abundance, but the highest abundance was at both the offshore and the nearshore flank of the Angola Current. This included the neighbouring layers with northward flow. There were noticeable catches even above the continental slope, in northward flow, at slightly greater depths than offshore (Fig. 8).

Along $20^{\circ} \mathrm{S}$, the tropical community seems to have occurred at depths greater than at $17^{\circ} \mathrm{S}$, since the uppermost stratum was devoid of tropical larvae. However, mean weighted depths differed but slightly $\left(51 \mathrm{~m}\right.$ at $17^{\circ} \mathrm{S}$ and $55 \mathrm{~m}$ at $\left.20^{\circ} \mathrm{S}\right)$.
In the open ocean at $20^{\circ} \mathrm{S}$ the tropical community had a much reduced relative abundance, but at $11.3^{\circ} \mathrm{E}$ (and perhaps part of the sampling gap with ACI water) it still contributed $>60 \%$ to the total MCN catch (Fig. 9). The respective TN complex comprised only two leptocephali each of eels Echelus pachyrhynchus (a shelf edge species) and Dalophis boulengeri (from shallow waters), but at the same position the NEU also contributed two TN larvae (Ariosoma balearicum and Trachinotus ovatus).

Species composition was also impoverished along $20^{\circ} \mathrm{S}$, with the complete disappearance of $\mathrm{V}$. nimbaria. Hygophum macrochir dominated on a relative scale, although being rare compared with its rank place 2 off Angola (John et al. 2001). Larval $H$. macrochir at $20^{\circ} \mathrm{S}$ were larger than at $17^{\circ} \mathrm{S}$, or in the Angolan Gyre (Fig. 10). Species 

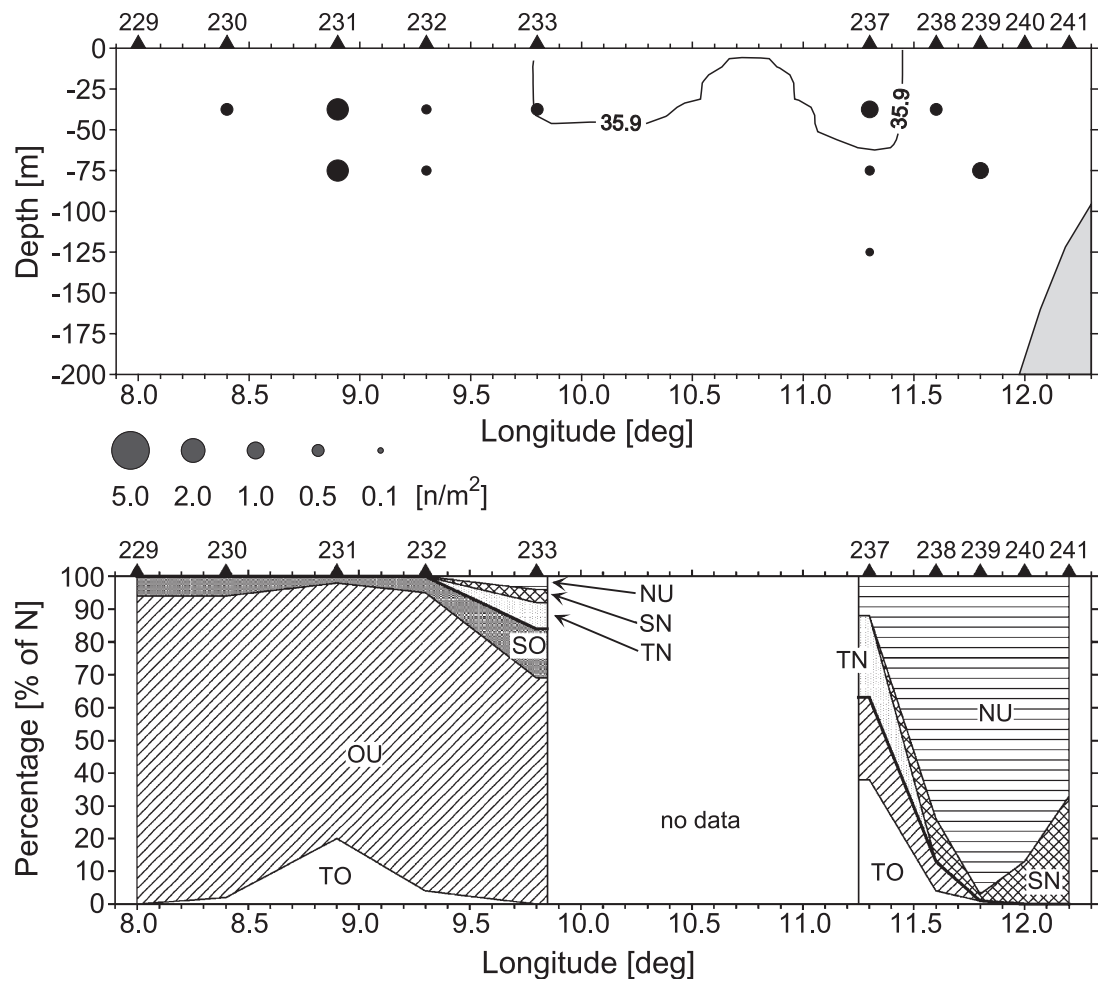

Fig. 9. The zonal and vertical abundance of fish larvae of tropical origin, and the relative faunistic composition along broadly $20^{\circ} \mathrm{S}$. Same as in Fig. 8 .

from the open ocean to the south were also found, but their occurrence relative to the contemporaneous flow field was inconsistent (compare Figs. 5 and 9). As shown further below (Fig. 12), H. macrochir occurred also in areas with strong northward flow, particularly at three stations within the Benguela upwelling regime. Three $B$. argyrogaster caught far offshore were also large, transforming larvae and were found in the depth layer $50-75 \mathrm{~m}$, i.e., below the northward flow at that position. The survey

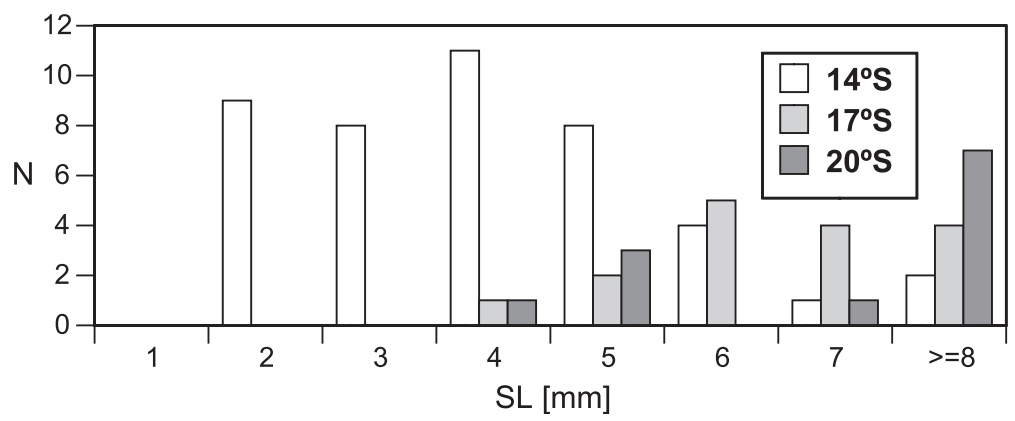

Fig. 10. The latitudinal length distribution of tropical oceanic larval H. macrochir. Comparative length data from $14^{\circ} \mathrm{S}$ are from John et al. (2001). 
yielded also adult $H$. macrochir at three offshore stations, together with adult and larval Symbolophorus kreffti, also from the TO community. One adult
H. macrochir was caught at $17^{\circ} \mathrm{S}$ in $\mathrm{MCN}$ at $8.7^{\circ} \mathrm{E}$, and five adults in NEU samples at $20^{\circ} \mathrm{S}$ (Fig. 11).
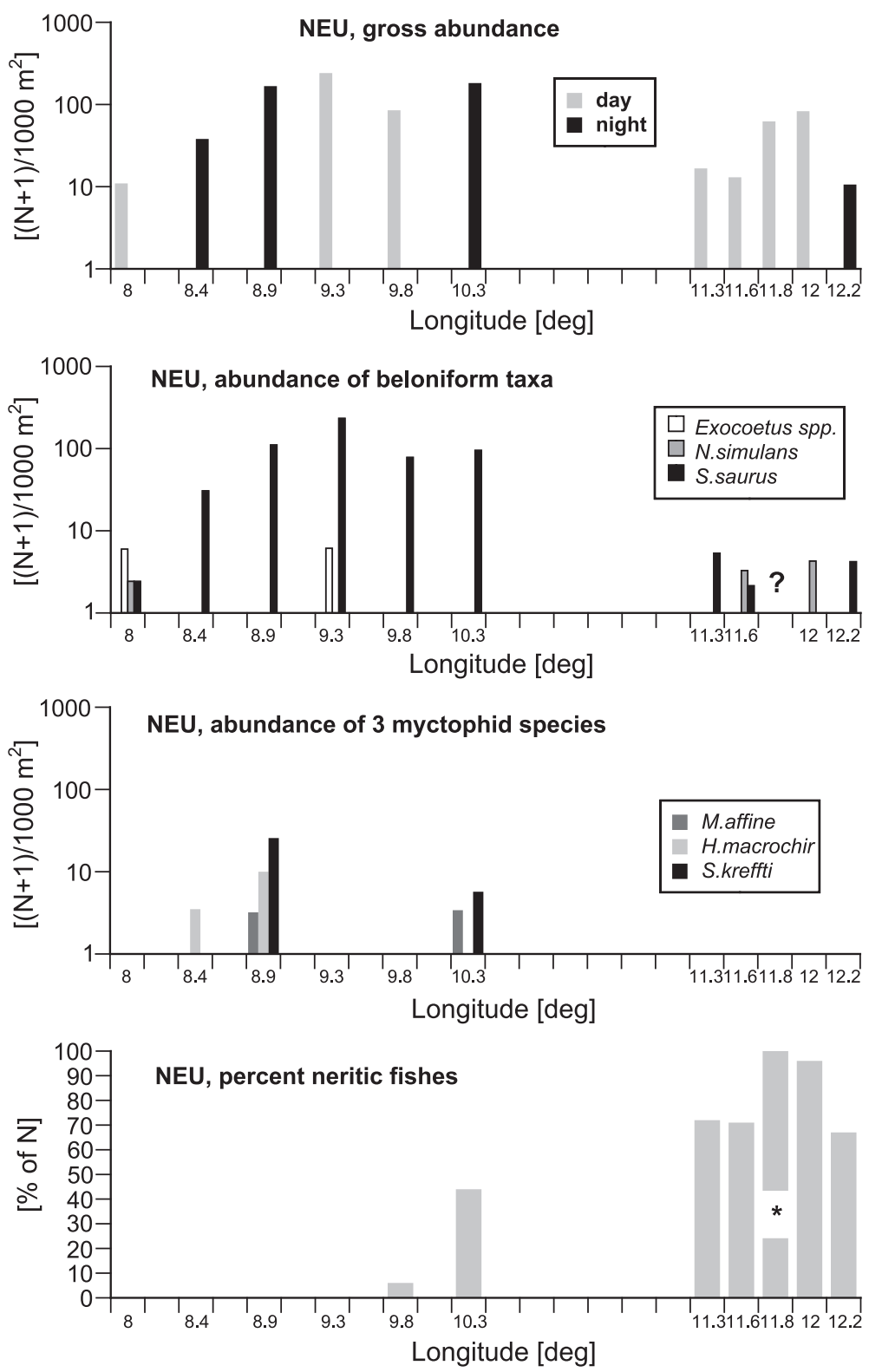

Fig. 11. Neustonic fishes along broadly $20^{\circ} \mathrm{S}$. Upper panel: gross abundances, separated for daytime and nighttime catches (black, respectively white columns). Second panel: occurrences of three neustonic species characteristic for faunal communities TO (Exocoetus spp.), CW (Nanichthys simulans), and SO (Scomberesox saurus). Third panel: occurrences of adults of three tropical myctophid species. These nyctoepipelagic species cannot be caught by the daytime NEU samples east of $11^{\circ} \mathrm{E}$. Bottom panel: the relative abundance of coastal fishes among the gross catch. The asterisk at $11.8^{\circ} \mathrm{E}$ indicates data from the lower NEU-net only, which may underrepresent neustonic taxa and overestimate the respective coastal species. 


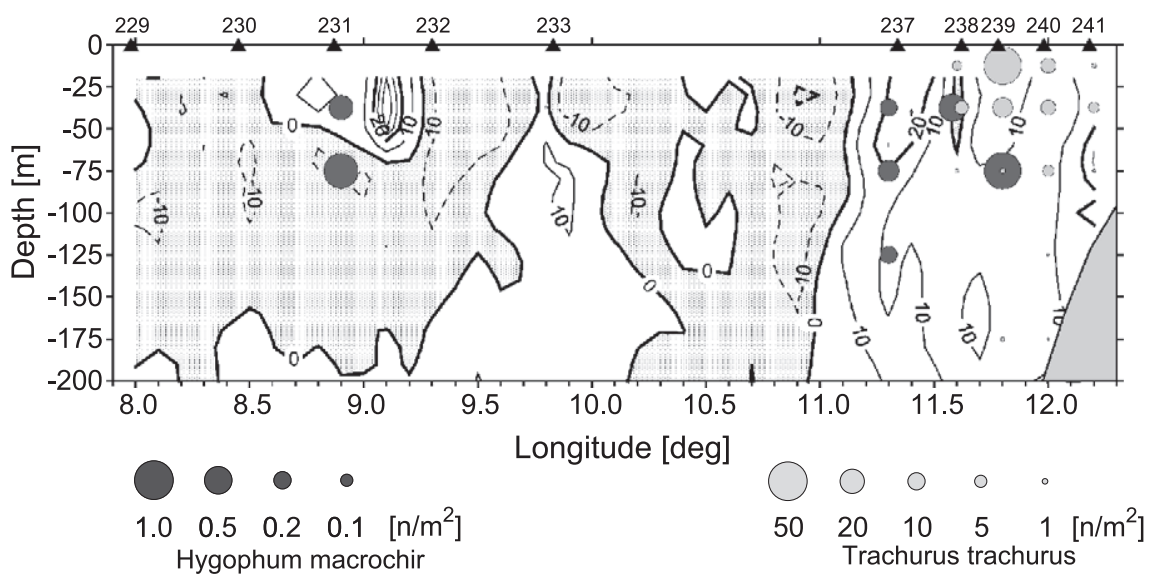

Fig. 12. The overlap of tropical oceanic species (exemplified by H. macrochir) and coastal species (exemplified by T. trachurus) along broadly $20^{\circ} \mathrm{S}$. Overlaid is the meridional flowfield (white= equatorward, shaded=southward). The second ranking coastal species $E$. capensis had a horizontal distribution similar to that of $T$. trachurus, but occurred shallower.

\subsection{Southern species}

Along $17^{\circ} \mathrm{S}$, no fish larvae from the southern oceanic community could be identified. Southern neritic fishes occurred exclusively at the four nearshore stations, but their relative and absolute abundance started decreasing from midshelf seawards, the fauna changing to tropical species (Fig. 8). This sharp boundary coincides with the change from high velocities of northward flow inshore to a slight southward flow and Ekman drift towards the open ocean. Besides a single Arnoglossus capensis, 18 sardines Sardinops ocellatus, a species of more temperate waters were found. Sardine lengths of $9.8-14.7 \mathrm{~mm}$ were similar between stations. On the basis of Table 1 , the spawning dates of sardines should all have been before the onset of upwelling, namely at and before 7 April, with a mode 31 March to 1 April. Surprisingly, no anchovies Engraulis capensis were found here, although their temperature preferences are higher and should perhaps match better the in-situ conditions. Horse mackerel $T$. trachurus was rare at $17^{\circ} \mathrm{S}$.

Along $20^{\circ} \mathrm{S}$, southern oceanic species occurred consistently at the offshore stations. Besides the 2 species listed in Table 3, Protomyctophum chilensis?, Diplospinus multistriatus, and Tetragonurus cuvieri were caught, and in NEU saury Scomberesox saurus became abundant (Fig. 11). Their inshore boundary could not be established, because

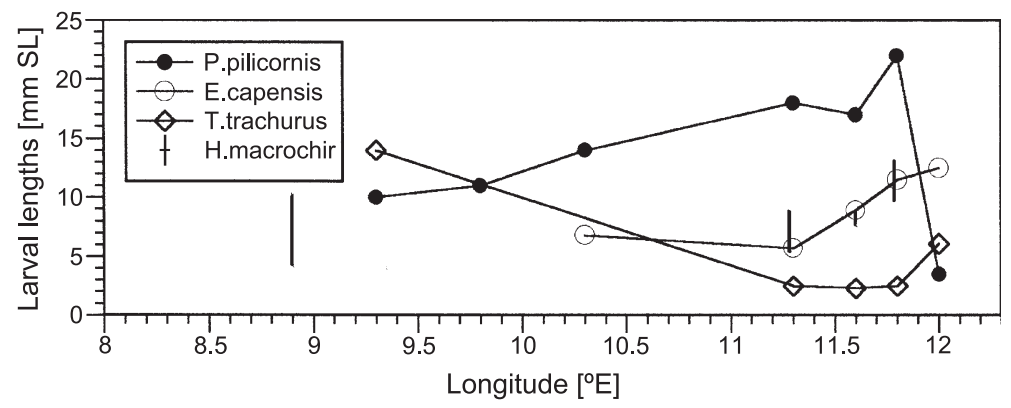

Fig. 13. The zonal distributions of modal lengths for the three coastal species E. capensis, P. pilicornis and T. trachurus along $20^{\circ} \mathrm{S}$ (curves). Superimposed (vertical bars) are the length ranges of tropical oceanic H. macrochir. 
it fell in the gap of stations. A comparison of Figs. 9 and 11 with the hydrographical sections in Fig. 5 shows that the southern oceanic fauna extended into the temperature and salinity maximum indicative for the Angola Current waters, and vertically also into strata with prevailing southward flow. Although the relative maximum of SO larvae coincided with a flow reversal to the north, abundance maxima fell into the regime of southward flow.

No southern oceanic species were found inshore of the station gap. There southern neritic species, surprisingly, overlapped horizontally with tropical oceanic and few tropical neritic larvae, as exemplified by Fig. 12. Besides the NU species T. trachurus, nearshore $P$. pilicornis were dominant. Furthermore, the neritic complex was composed of anchovy, five round herring Etrumeus whiteheadi restricted to $12.0^{\circ} \mathrm{E}$, and a single Sufflogobius bibarbatus. Anchovy larvae had a horizontal distribution similar to that of Trachurus, but occurred exclusively in the upper $50 \mathrm{~m}$. Whilst $P$. pilicornis was caught mainly in the neuston net, the vertical distributions of T. trachurus and E. capensis larvae were as described in the literature (O'Toole, 1977; Olivar, 1990).

Our horse mackerel larval material does not contain any yolk sac larvae, indicating a minimum age of 6 days. Modal lengths in the 3-mm-size class (Fig. 13) above the continental slope therefore point to ages of 6-9 days, and birthdays between 14 and 17 April. The nearshore mode in the 6-mm-size class is estimated to represent an age of 14 days (spawning around 10 April).

A calculation of anchovy birthdays from lengths (Table 1, Fig. 13) suggests that the youngest anchovies were born on 13-15 April, before the wind event. The bulk was spawned before 8 April, and as far back as 19 March. The much larger anchovy larvae above the outer shelf were probably born between 28 March and 10 April.

It should be mentioned here that postflexion anchovy and sardine larvae (birthdays before 3 April and therefore before the period of interest here) were likely to be undersampled by our gear. At first glance it is surprising that the smallest anchovy and horse mackerel larvae occurred offshore, and together with large larvae of $H$. macrochir.

\section{Discussion and conclusions}

The coastal upwelling regime along both transects showed a faunistic composition influenced by the warmer than usual conditions, agreeing with earlier conclusions by Olivar (1990) and Olivar and Shelton (1993). Although April is already beyond the peak spawning season of anchovy, sardine and horse mackerel, these three species should be dominant among the coastal fish larvae (Le Clus, 1990; Olivar, 1990; Olivar and Rubiés, 1983; Sedletskaya, 1988). Inshore temperatures should have been optimum for horse mackerel T. trachurus, the occurrence of which in fact proved to be rare, and they should favour anchovy spawning instead of sardine. However, the low abundances of anchovy and horse mackerel conformed broadly with the warm autumn situation described by Olivar and Barangé (1990). In historical data the inshore part off northern Namibia was dominated by sardine larvae (Le Clus, 1990, and references therein).

The bulk of the pelagic coastal larvae was spawned before the onset of upwelling (Fig. 2; the wind speed observed on board increased to above $10 \mathrm{~m} \mathrm{~s}^{-1}$ in the evening of 15 April). High wind speed seems to have suppressed spawning of neritic fish. It is generally assumed that recruitment of pelagic fish species in upwelling systems needs an optimum environmental window of wind speeds of $5-6 \mathrm{~m} \mathrm{~s}^{-1}$ at and after spawning in order to reduce dispersal of food by turbulence, and loss of larvae offshore (e.g., Parrish et al., 1983; Cury and Roy, 1989). The AngolanNamibian upwelling region has recently experienced a sequence of warmer years than average (1993-1999; Hagen et al., 2001). This may be one of the mechanisms causing the decline of the northern Namibian sardine stock (Boyer et al., 2001).

The faunistic composition of oceanic larvae in general conformed well with the inventory given by Olivar and Fortuño (1991). Adults of B. argyrogaster, H. macrochir and S. kreffti have not been found off Namibia previously, but their larvae have been reported above the northern Namibian continental slope (Olivar and Fortuño, 1991). These were explained to have been carried into the Benguela system by the poleward undercurrent (John et al., 2000; review). The actual presence of adult H. macrochir and S. kreffti in the region in April 1999 might 
suggest that the larval catches in question (or the few at $19^{\circ} \mathrm{S}$ in the open ocean, shown by John et al., 2001) result from spawning at these latitudes. This seems contradicted by the latitudinal length distributions illustrated in Fig. 10, that show that these larvae were distinctly larger/older than in the Angolan spawning area.

Lacking comparative historical data for the position of the ABFZ at $H$. macrochir's daytime depth $(>400 \mathrm{~m})$, we suspect an extreme southerly position of the water mass boundary between ESACW and SACW during the survey (Mohrholz et al., 2001). The water mass front slanted southeastwards, which might have allowed the species also to occur above the continental slope along $20^{\circ} \mathrm{S}$, but our samples could not have revealed their presence there since all slope stations were carried out during daytime.

Instead of assuming spawning of tropical mesopelagic fish species off northern Namibia, we postulate that the larvae had originated farther north and had been advected southwards by the Angola Current. Due to the intense mixing at the edge of the ACI they might have left the Angola Current water and may have been seeded into the ambient water masses. They might also have been entrained by a previously existing slope undercurrent. As already mentioned such an undercurrent was visible at Angolan slope stations along $15^{\circ} \mathrm{S}$ (as shown by Schmidt et al., 2000, p. 23, Fig. 9), but may subsequently have been suppressed by strong equatorward wind stress. At the time of catch the larvae were at least temporarily and locally on their way back towards lower latitudes. The horizontal geostrophic flow field (Fig. 14) shows that the ABFZ meandered across the southern transect in the preferred depth of these larvae, and that the southward flows in the ADCP data along $20^{\circ} \mathrm{S}$ did not extend into higher latitudes at this time.

As shown above, there was good conformity between the zonal water mass distribution and faunistic structures in the upper $40-60 \mathrm{~m}$ depth along both transects. There also was good correspondence with the respective synoptic SST and SeaWiFS images. Assuming such consistency also for the area between both transects, the warm Angola Current Intrusion (ACI) visible in these images should (and does) describe the southward path of fish larvae of tropical neritic as well as tropical oceanic origin fairly well.
For the northern transect conformity was also good for the contemporaneous flow field, revealing a sharp separation between the narrow upwelling regime and the prevailing tropical regime offshore.

However, along the southern transect, there existed discrepancies between the faunistic structure and the contemporaneous flow, and occasionally within some of the biological data proper, which require further discussion.

Along the southern transect at about $11.5^{\circ} \mathrm{E}$, a steep front from the surface to some $70 \mathrm{~m}$ depth is evident in the CTD data (including fluorescence). It is also apparent in the cross-slope faunistic structure, thus distinctly separating the cool Benguela upwelling regime from tropical Angola Current waters. Both regimes had broadly identical geographical scales in most hydrographical and biological characteristics. In the ADCP data the upwelling front was located by one station farther offshore, suggesting that the flow reacted faster to changing wind conditions than water masses (Kostianoy and Lutjeharms, 1999). The northward flow covered the entire $200 \mathrm{~m}$ depth range investigated here. The southward Angola Current also reached down to $200 \mathrm{~m}$, but was narrower and weaker at depth. Reversals in the meridional flow field offshore, seemingly contrasting with the tropical origin of the respective indicator species contained, has been shown above to be due to small-scale features only in temporarily westward flow. At a first glance the characteristics of the Benguela upwelling and Angola Current regimes therefore seem to be relatively homogeneous individually, except for an overlay of the Angola Current by coastal fish larvae (mainly blenny $P$. pilicornis) entrained offshore by Ekman drift.

However, within the coastal jet proper there also was an inconsistency, centered between stations 238 and 239 at about $11.6^{\circ} \mathrm{E}$. The inconsistency is inconspicuous in any of the gross fish larval data, in which the neritic community seemed to extend by one station farther offshore. However, it is expressed by a chlorophyll-a maximum (to be expected shoreward of the upwelling front some 4 days after onset of the wind), a minimum of northward flow, adjacent onshore flow, a surprising occurrence of tropical oceanic larvae below the neritic ones (Fig. 12), and distinctly different larval lengths for most species of coastal fishes. At these stations minimum lengths were en- 


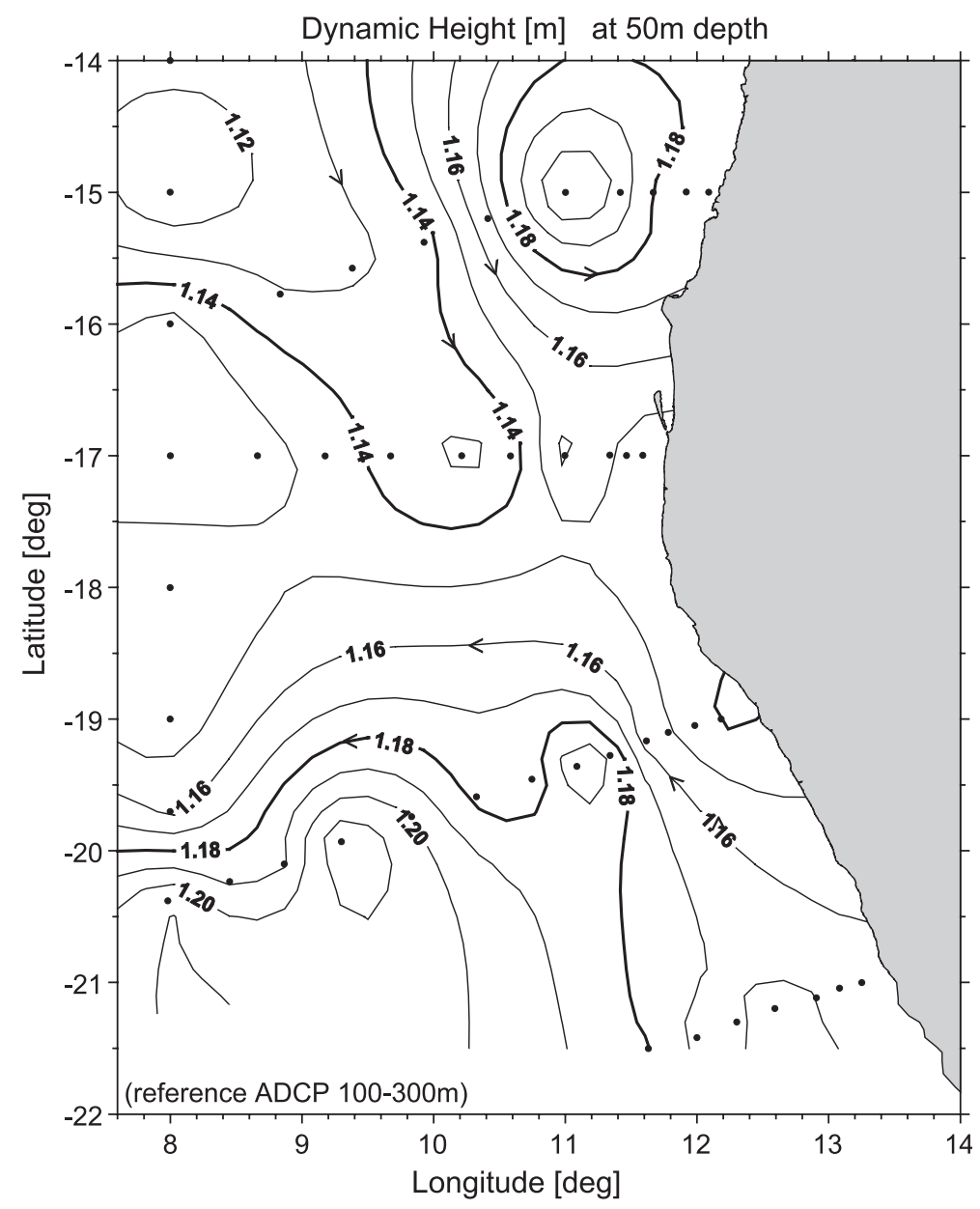

Fig. 14. The flow field at $50 \mathrm{~m}$ depth (arrows) derived from dynamic height (from John et al., 2001, modified).

countered for anchovy and horse mackerel, and maximum lengths for blenny (Fig. 13).

In upwelling systems, shallow-living larvae of coastal fish species are generally expected to drift offshore with the Ekman drift, and to increase in size (age) with distance offshore. For northern Namibia these patterns have been corroborated by Olivar (1990) for, among others, blenny P. pilicornis, anchovy, sardine, and horse mackerel (species sequenced here from intertidal to deeper shelf spawning habitats). In our material only P. pilicornis, for which no length/age data are available, showed a conforming behaviour above the shelf and continental slope (Fig. 13), but not so at the stations farthest offshore beyond the gap of sampling. It should be mentioned here that the smallest larvae nearshore were caught by the MCN, whilst all catches west of $12.0^{\circ} \mathrm{E}$ were contributed exclusively by the neuston net.

The cross-coast length distributions in almost all species contradict the expectation of uniform offshore dispersal with the Ekman drift, and thus also contradict any homogeneity of the cross-slope faunal structure. So does the co-occurrence of larvae of tropical oceanic mesopelagic fish $H$. macrochir plus $2 D$. boulengeri, overlapping horizontally (although centered more to the west and deeper) with the young larvae of coastal fish.

The age estimates given above suggest that the inconsistency must have come about when the bulk of the midshelf fauna was entrained some 6-9 days 
previously, but also had received input from shallow waters several times earlier. On the other hand, larvae of tropical origin must have been entrained at this time (or earlier, the mentioned eel larvae and B. podas can be classified as "teleneritic", see, e.g., Evseenko, 1982; John and Zelck, 1997) at the stations to the west of the inconsistency. We interpret the warmer patch of water in the synoptic SST satellite image visible at $19-20^{\circ} \mathrm{S}$, $11.0-11.5^{\circ} \mathrm{E}$ (Fig. 15), together with the geostrophic flow field, and the ADCP data, as expression of a mesoscale anticyclonic gyre. Such a gyre-like, far more isolated, structure was visible in the satellite SST image from 19-21 April (Mohrholz et al., in press), and was probably generated by friction between the opposite flows of the Angola Current and the coastal jet. Earlier satellite SST images show the Angola Current following the Angolan continental slope, and spreading onto the northern Namibian shelf, at least on 10-12 April (Mohrholz et al., in press).

The geostrophic adjustment of the warm ACI results in an anticyclonic circulation around the tip of the ACI tongue. Our southern transect crossed its southern tip where mixing between the ACI water and the Benguela water was intense, and we interpret the mentioned SST image to show the rudiment of a dispersed mesoscale eddy there. The anticyclonic circulation around the ACI may have transported TO larvae onshore where they mixed with neritic

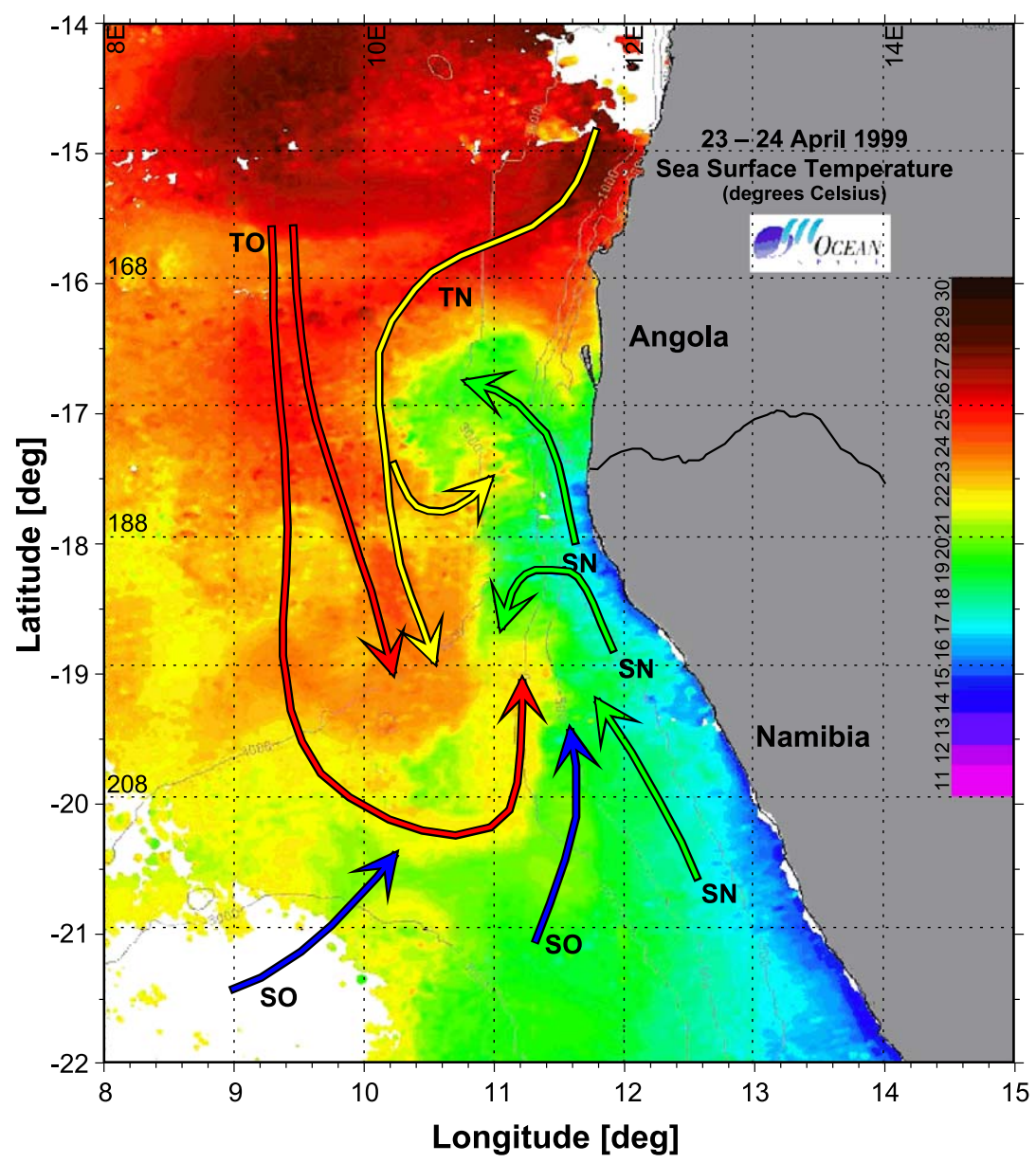

Fig. 15. The sea surface temperature distribution at the time of surveying the southern transect, overlaid by a conceptual model suggesting advective paths of faunistic elements relative to the anticyclonic circulation at the tip of the Angola Current intrusion into northern Namibian waters. Abbreviations are the same as for Figs. 8 and 9, respectively, and Table 3. 
species from the Benguela upwelling regime. Fig. 15 presents a conceptual transport model for the faunistic elements relative to the anticyclonic circulation at the tip of the ACI. Due to the geostrophic velocity field we should expect that the abundance of TO species was at a maximum at both edges of the ACI, whereas the oldest TO larvae should (and did, Fig. 13) occur in the eastern rim nearer to the coast than the younger larvae. The high meridional velocities nearshore might have caused the advection of the coastal larvae from anywhere, and since larvae where age estimates were at all possible were caught only at the eastern margin of this gyral structure, we cannot reasonably calculate any advection rates for them.

\section{References}

Ahlstrom, E.H., 1973. Handling the collections ashore. In: Hempel, G. (Ed.), Fish Egg and Larval Surveys (contributions to a manual). FAO Fish. Tech. Pap., vol. 122, pp. 27-32.

Bekker, V.E., 1983. The Myctophid Fishes of the World Ocean. Nauka Press, Moscow, p. 247. In Russian.

Boyer, D., Boyer, H.J., Fossen, I., Kreiner, A., 2001. Changes in abundance of the northern Benguela sardine stock during the decade 1990-2000, with comments on the relative importance of fishing and the environment. S. Afr. J. Mar. Sci. 23, 67-84.

Brownell, C.L., 1983. Laboratory rearing of Cape anchovy Engraulis capensis and South African pilchard Sardinops ocellata through metamorphosis. S. Afr. J. Mar. Sci. 1, 181-188.

CLOFETA, 1990. Quéro, J.C., Hureau, J.C., Karrer, C., Post, A., Saldanha, L. (Eds.), 1990. Check-List of the Fishes of the Eastern Tropical Atlantic: I-III. UNESCO, Paris. 1492 pp.

Cury, P., Roy, C., 1989. Optimal environmental window and pelagic fish recruitment success in upwelling areas. Can. J. Fish. Aquat. Sci. 46, 670-680.

Ekau, W., Hendricks, A., Kadler, S., Koch, V., Loick, N., 2001. Winter ichthyoplankton in the northern Benguela upwelling and Angola-Benguela Front regions. S. Afr. J. Sci. 97 (5-6), 259-265.

Evseenko, S.A., 1982. Eco-morphological peculiarities of the early life history of flatfishes of the western North Atlantic. Trudy Inst. Okean. 118, 43-84 (in Russian).

Firing, E., Ranada, J., Caldwell, P., 1995. Processing ADCP data with CODAS Software, Version 3.1. Technical Report. Joint Institute for Marine and Atmospheric Research, University of Hawai, USA.

Florenchie, P., Lutjeharms, J.R.E., Reason, C.J.C., Masson, S., Rouault, M., 2003. The source of Benguela Niños in the South Atlantic Ocean. Geophys. Res. Lett. 30, 1505 (doi:1029/ 2003GLO17172).

Hagen, E., Feistel, R., Agenbag, J.J., Ohde, T., 2001. Seasonal and interannual changes in intense Benguela upwelling (19821999). Oceanol. Acta 24 (6), 557-568.

Hulley, P.A., 1981. Results of the research cruises of FRV "Walther Herwig" to South America: LVIII. Family Myctophidae (Osteichthyes, Myctophiformes). Arch. Fisch.Wiss. 31 (Beih.1), $1-300$.

John, H.-Ch., Zelck, C., 1997. Features, boundaries and connecting mechanisms of the Mauritanian province exemplified by oceanic fish larvae. Helgol. Meeresunters. 51 (2), 213-240.

John, H.-Ch., Klenz, B., Hermes, R., 1991. Distribution and drift of horse mackerel larvae (genus Trachurus) off Mauritania January to April 1983. ICES, C.M. H:3. 22 pp.

John, H.-Ch., Zelck, C., Erasmi, W., 2000. Poleward transport of equatorial fish larvae in the Atlantic Eastern boundary current system. Arch. Fish. Mar. Res. 48 (1), 61-88.

John, H.-Ch., Mohrholz, V., Lutjeharms, J.R.E., 2001. Cross-front hydrography and fish larval distribution at the Angola-Benguela Frontal Zone. J. Mar. Sys. 28 (1-2), 91-111.

Johnson, R.K., 1986. Polytypy, boundary zones and the place of broadly distributed species in mesopelagic zoogeography. In: Pierrot-Bults, A.C., Van Der Spoel, S., Zahuranec, B.J., Johnson, R.K. (Eds.), Pelagic Biogeography. UNESCO Tech. Pap. Mar. Sci., vol. 49, pp. 156-165.

King, D.P.F., 1977. Influence of temperature, dissolved oxygen and salinity on incubation and early larval development of the south west African pilchard Sardinops ocellata. Invest. Rep. Sea Fish. Brch. S. Afr. 114 (35 pp.).

King, D.P.F., O’Toole, M.J.O., Robertson, A.A., 1977. Early development of the south African Maasbanker Trachurus trachurus at controlled temperatures. Fish. Bull. S. Afr. 9, 16-22.

King, D.P.F., Robertson, A.A., Shelton, P.A., 1978. Laboratory observations of the early development of the anchovy Engraulis capensis from the Cape Peninsula. Fish. Bull. S. Afr. 10, 37-45.

Kostianoy, A.G., Lutjeharms, J.R.E., 1999. Atmospheric effects in the Angola-Benguela Frontal Zone. J. Geophys. Res. 104 (C9), 20963-20970.

Le Clus, F., 1990. Impact and implications of large-scale environmental anomalies on the spatial distribution of spawning of the Namibian pilchard and anchovy populations. S. Afr. J. Mar. Sci. $9,141-160$.

Longhurst, A., 1962. A review of the oceanography of the Gulf of Guinea. Bull. I.F.A.N. 24 A (3), 633-663.

Mayfield, S., Elliott, B., Giddey, C.J., 2001. Analysis of fish eggs and larvae collected in the region of the northern Benguela and Angola currents: preliminary results. S. Afr. J. Sci. 97 (5-6), 270.

Meeuwis, J.M., Lutjeharms, J.R.E., 1990. Surface thermal characteristics of the Angola-Benguela Front. S. Afr. J. Mar. Sci. 9, $261-279$.

Mohrholz, V., Schmidt, M., Lutjeharms, J.R.E., 2001. The hydrography and dynamics of the Angola-Benguela Frontal Zone and environment in April 1999. S. Afr. J. Sci. 97, 199-208.

Mohrholz, V., Schmidt, M., Lutjeharms, J.R.E., John, H.-Ch., 200x. Space-time behaviour of the Angola-Benguela Frontal Zone during the Benguela Niño of April 1999. Int. J. Remote Sens. (in press).

Nafpaktitis, B.G., Backus, R.H., Craddock, J.E., Haedrich, R.L., 
Robison, B.H., Karnella, C., 1977. Family Myctophidae. Fishes of the Western North Atlantic. Mem. Sears Found. Mar. Res., vol. 1 (7), pp. 13-265.

Olivar, M.-P., 1990. Spatial patterns of ichthyoplankton distribution in relation to hydrographic features in the northern Benguela region. Mar. Biol. 106, 39-48.

Olivar, M.P., Barangé, M., 1990. Zooplankton of the northern Benguela region in a quiescent upwelling period. J. Plankton Res. 12 (5), 1023-1044

Olivar, M.-P., Fortuño, J.-M., 1991. Guide to ichthyoplankton of the Southeast Atlantic. (Benguela Current Region). Sci. Mar. 55 (1), $1-383$.

Olivar, M.-P., Rubiés, P., 1983. Distribution and abundance of Cape horse mackerel (Trachurus trachurus capensis) eggs and larvae caught during the Benguela III cruise (March-April 1981). Collect. Sci. Pap. - Intern. Comm. Southeast Atl. Fish. II, $161-172$.

Olivar, M.P., Shelton, P.A., 1993. Larval fish assemblages of the Benguela Current. Bull. Mar. Sci. 53 (2), 450-474.

Olivar, M.P., Moser, H.G., Hartel, K.E., Lombarte, A., 1993. Larvae of three species of Bathylagus of the Southern Atlantic. Copeia 2, 503-513.

O’Toole, M.J., 1977. Influence of some hydrological factors on the depth distribution of Maasbanker (Trachurus trachurus) larvae off South West Africa. Fish. Bull. (RSA) 9, 46-47.

Parrish, R.H., Bakun, A., Husby, D.M., Nelson, C.S., 1983. Comparative climatology of selected environmental processes in relation to eastern boundary current pelagic fish production. FAO Fish. Rep. 291 (3), 731-777.
Penrith, M.J., 1978. An annotated check-list of the inshore fishes of southern Angola. Cimbebasia A 4 (11), 179-190.

Schmidt, M., Mohrholz, V., Schmidt, T., John, H.-Ch., Weinreben, S., Diesterheft, H., Iita, A., Filipe, V., Sangolay, B.B., Kreiner, A., Hashoongo, V., da Silva Neto, D., 2000. Data report of R/V "Poseidon" cruise 250. ANDEX' 1999. Meereswiss. Ber. 40 (117 pp.).

Sedletskaya, V.A., 1988. Reproduction of Cape hake (Merluccius M. capensis) and Cape horse mackerel (Trachurus t. capensis) in Namibia. Collect. Sci. Pap. - Intern. Comm. Southeast Atl. Fish., 215-222.

Shannon, L.V., 1985. The Benguela ecosystem: Part I. Evolution of the Benguela, physical features and processes. Oceanogr. Mar. Biol. Annu. Rev. 23, 105-182.

Shannon, L.V., Boyd, A.J., Brundrit, G.B., Taunton-Clark, J., 1986. On the existence of an El Niño-type phenomenon in the Benguela system. J. Mar. Res. 44, 495-520.

Shannon, L.V., Agenbag, J.J., Buys, M.E.L., 1987. Large- and mesoscale features of the Angola-Benguela Front. S. Afr. J. Mar. Sci. 5, 11-34

Smith, M., Heemstra, P.C. (Eds.), 1986. Smith's Sea Fishes. Macmillan, Johannesburg. $1047 \mathrm{pp}$.

Steedman, H.F., 1976. Zooplankton fixation and preservation. Monogr. Oceanogr. Method., vol. 4. UNESCO, Paris. 350 pp.

Thomas, R.M., 1986. Growth of larval pelagic fish in the SouthEast Atlantic from daily otolith rings in 1982/83 and 1983/84. S. Afr. J. Mar. Sci. 4, 61-77.

Whittaker, R.H., 1975. Communities and Ecosystems. MacMillan, New York. 385 pp. 